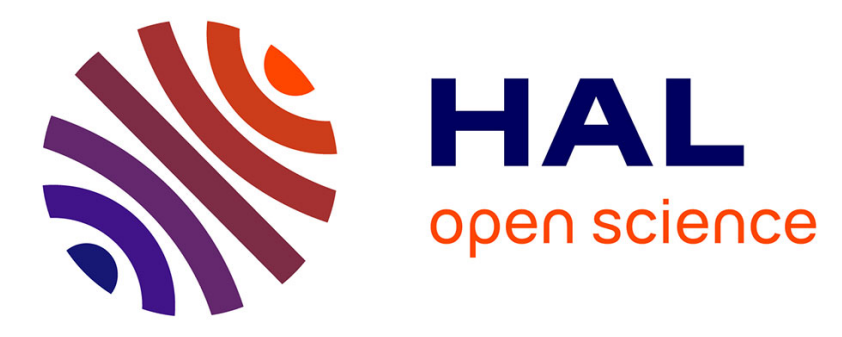

\title{
Laboratory-Scale Bio-Treatment of Real Arsenic-Rich Acid Mine Drainage
}

Fabienne Battaglia-Brunet, Corinne Casiot, Lidia Fernandez-Rojo, Marina Hery, Pierre Le Pape, Hafida Tris, Guillaume Morin, Solène Touzé, Catherine Joulian

\section{To cite this version:}

Fabienne Battaglia-Brunet, Corinne Casiot, Lidia Fernandez-Rojo, Marina Hery, Pierre Le Pape, et al.. Laboratory-Scale Bio-Treatment of Real Arsenic-Rich Acid Mine Drainage. Water, Air, and Soil Pollution, 2021, 232 (8), pp.330. 10.1007/s11270-021-05276-z . hal-03365805

\section{HAL Id: hal-03365805 https://hal.science/hal-03365805}

Submitted on 5 Oct 2021

HAL is a multi-disciplinary open access archive for the deposit and dissemination of scientific research documents, whether they are published or not. The documents may come from teaching and research institutions in France or abroad, or from public or private research centers.
L'archive ouverte pluridisciplinaire HAL, est destinée au dépôt et à la diffusion de documents scientifiques de niveau recherche, publiés ou non, émanant des établissements d'enseignement et de recherche français ou étrangers, des laboratoires publics ou privés. 


\section{Laboratory-scale Bio-treatment of Real Arsenic-rich Acid}

\section{Mine Drainage}

3 Battaglia-Brunet Fabienne ${ }^{(*)}$, Casiot Corinne, Fernandez-Rojo Lidia, Hery Marina, Le Pape

4 Pierre, Tris Hafida, Morin Guillaume, Touzé Solène, Joulian Catherine

5 F. Battaglia-Brunet (*), H. Tris, S. Touzé, C. Joulian: BRGM, Water, Environment, Process

6 Development and Analysis Division, 3 av. Claude Guillemin, BP 36009, 45060, Orléans Cedex

7 2, France

8 (*) e.mail: f.battaglia@brgm.fr ORCID 0000-0002-4005-6290

9 C. Casiot, L. Fernandez-Rojo, M. Hery: HydroSciences Montpellier, Univ Montpellier, CNRS, 10 IRD, Montpellier, France

P. Le pape, G. Morin: Institut de Minéralogie, de Physique des Matériaux et de Cosmochimie (IMPMC), UMR 7590 CNRS-SU-IRD-MNHN, Sorbonne Université, case115, 4 place Jussieu, 75252 Paris Cedex 05, France

\section{Abstract}

Acid mine drainage (AMD) still represents a huge environmental problem. Technical and scientific breakthroughs are still needed to decrease environmental damages, treatment cost and waste production associated with AMD. The feasibility of combining continuously fed anaerobic sulfate-reducing bioreactor with downstream iron oxidation step was tested, at laboratory scale, with two types of real arsenic rich AMD waters from the site of Carnoulès (France), that differed in acidity (pH 3.3 and 4.0), arsenic (As, 18 and $174 \mathrm{mg} / \mathrm{L}$ ) and metals concentrations. Iron remained in solution while up to $99 \%$ of As was precipitated as amorphous orpiment in the anaerobic sulfate-reducing bioreactor. Zinc ( $\mathrm{Zn}$ ) precipitation was also 
observed, up to 99\%, however the efficiency of Zn precipitation was less stable than that of As. The anaerobic bioreactor presented a stable bacterial community including a Desulfosporosinus-related sulfate-reducer. When the effluents from the anaerobic process step were treated in a laboratory aerobic bioreactor, iron was oxidized efficiently. The feasibility of efficient orpiment bio-precipitation coupled with downstream iron oxidation was shown, thus opening the perspective of low-cost combination of treatment steps for the removal of arsenic, zinc and iron in As-rich AMDs.

Key words arsenic, acid mine drainage, bioreactors, sulfate-reduction, bio-oxidation

\section{Introduction}

Acid mine drainage (AMD) causes extensive damage to the aquatic environment all around the world (Simate and Ndlovu, 2014). This phenomenon affects many abandoned and remote sites, where the application of the classical active lime treatment is technically and economically problematic. Passive or semi-passive technologies have been developed, the global remediation strategy generally involving several biological or physic-chemical treatment steps (Johnson and Hallberg, 2005; Nairn et al., 2010; Mattes et al., 2011). Oxidation steps can be efficient to remove iron $(\mathrm{Fe})$, manganese $(\mathrm{Mn})$, or co-precipitate $\mathrm{Fe}$ and arsenic (As) (Casiot et al., 2003;

Battaglia-Brunet et al., 2006; Wang et al., 2006; De Sa et al., 2010; Nairn et al., 2010; Fernandez-Rojo et al., 2017, 2019). However, such aerobic processes are unsuitable for the removal of divalent metal cations due to their poor sorption onto positively charged surface of Fe-oxyhydroxides in acid conditions (Lee et al., 2002). On a complementary way, biological reduction of sulfate efficiently removes metals such as zinc $(\mathrm{Zn})$, copper $(\mathrm{Cu})$, and lead $(\mathrm{Pb})$ as metallic sulfide precipitates and induces an increase of alkalinity and $\mathrm{pH}$ (Kaksonen and Puhakka, 2007, Touzé et al., 2008). This treatment is also efficient to remove As (Mattes et al., 
2011), provided that low $\mathrm{pH}$ and/or low dissolved sulfide concentrations maintain sulfide amounts sufficiently low $\left(<1 \mathrm{mg} \cdot \mathrm{L}^{-1}\right)$ to avoid the formation of soluble thioarsenic species (Smieja and Wilkin, 2003). Sulfate reduction needs a costly supply in electron donor, such as hydrogen or organic molecules. To limit such costs, passive anaerobic bioreactors are generally filled with raw organic materials, such as agricultural, wood or food processing wastes which degradation provides electron donors for sulfate reduction (Parvis and Younger, 1999; Gibert et al., 2004; Mattes et al., 2011). However, in these systems, the sulfate-reducing activity cannot be regulated, all metals being precipitated as a bulk without selectivity. It would be interesting to regulate the activity of sulfate-reducing bacteria so as to remove only metals that cannot be eliminated, or only partially removed, in the aerobic steps. In this respect, iron sulfide (FeS) precipitation should be avoided since $\mathrm{Fe}$ can be efficiently treated in an oxidizing process (Fernandez-Rojo et al., 2017). Allocate the sulfate-reducing activity to the precipitation of a selection of metals will thus save organic substrate costs. Considering that FeS precipitates at pH higher than 5 (Kontopoulos, 1997), the sulfate-reducing bioreactor should be able to perform efficiently at lower $\mathrm{pH}$. Sulfate reduction by acidophilic or acido-tolerant sulfatereducing bacteria (SRB) has been reported as a promising way to remediate acid mine water while selectively precipitating metals as sulfides (Kimura et al., 2006; Johnson et al., 2009; Nancucheo and Johnson, 2012; Nancucheo et al., 2014; Sanchez-Andrea et al., 2015; Gonzales et al., 2019). The feasibility of As sulfide biosynthesis was demonstrated in batch laboratory bioreactors (Serrano and Leiva, 2017; Le Pape et al., 2017) or continuously fed with acidic (pH 2.5 to 4, Battaglia-Brunet et al., 2012; Altun et al., 2014) or mild acidic synthetic (pH 6-7, Rodriguez-Freire et al., 2014, 2015) solutions. Growth of SRB inducing precipitation of the orpiment and realgar, together with $\mathrm{ZnS}$ nanoparticles, has been proven in the real arsenic-rich acid mine water from Carnoulès site (France) in batch experiments (Le Pape et al., 2017). 
Here, the two steps of a semi-passive process configuration including complementary anaerobic and aerobic reactions were separately tested with the Carnoulès AMD in continuous laboratoryscale bioreactors. These two complementary processes should allow removal of toxic metals and high As contents from the AMD. Three main issues were addressed: (i) the feasibility of orpiment precipitation from real arsenic-rich acidic mine water in an anaerobic SRB bioreator, (ii) the separation of Fe, remaining in solution, from $\mathrm{Zn}$ and As, precipitated as sulfides, and (iii) the aerobic bio-oxidation of remaining Fe present in the effluent from the anaerobic bioreactor, and subsequent As removal.

\section{Materials and Methods}

\subsection{Mine waters}

AMD water was collected in July 2014 at the Carnoulès mine (Gard, France) from two different springs: $\mathrm{S} 1$ and SSR, filtrated at $0.45 \mu \mathrm{m}$ in a glovebox and stored at $5^{\circ} \mathrm{C}$ under nitrogen. $\mathrm{NaOH}$ solution (1 M) was added to the water in a glovebox when $\mathrm{pH}$ adjustment was needed. Characteristics of the water samples are given in Table 1. Among all metals and metalloids present in these mine waters, As is particularly toxic, $\mathrm{Zn}$ is the most concentrated divalent metal, and $\mathrm{Fe}$ is present at high level, close to 1 g.L $\mathrm{L}^{-1}$ (le Pape et al., 2017). 
2.2 Sulfate-reducing bioreactor

\subsubsection{Experimental device}

The sulfate-reducing bioreactor consisted of a $320 \mathrm{~mm}$ high and $35 \mathrm{~mm}$ internal diameter glass column, equipped with a water jacket for temperature regulation. The bioreactor filling method was conceived to: (1) test the passive distribution of nutrients to the bacteria, and (2) try to establish different levels of SRB activities in the bottom and the top zones based on the stimulation of SRB growth by yeast extract, thus testing the possibility to precipitate As in the top layer (lower sulfate-reduction activity) and $\mathrm{Zn}$ in the bottom layer. The bioreactor (Fig. 1) was filled in two distinct layers. For the top half of the bioreactor, pozzolana was mixed with hot liquid agar $\left(25\right.$ g. $\left.\mathrm{L}^{-1}\right)$ prepared with deionized water acidified at $\mathrm{pH} 4.5$ with $\mathrm{H}_{2} \mathrm{SO}_{4}$, containing 5 g.L $\mathrm{L}^{-1}$ glycerol and 0.5 g.L $\mathrm{L}^{-1} \mathrm{~K}_{2} \mathrm{HPO}_{4}$. After solidification of the agar, pozzolana grains were separated using a spatula and mixed with a carrier biomaterial named "biocompounds", provided by Vertum GmbH (Walter et al., 2009) and composed of polyhydroxybutyrate and polycaprolactone. The proportions of components were $160 \mathrm{~g}$ of pozzolana / $100 \mathrm{~g}$ of biocompounds / $200 \mathrm{~mL}$ of agar with nutrients. The bottom filling material had same composition except for the nutritive agar, supplemented with 1 g.L. $L^{-1}$ yeast extract. Sampling ports equipped with septa allowed liquid sampling from the middle, bottom and top levels.

The bioreactor was inoculated with a sulfate-reducing microbial consortium, enriched from sediments of the Carnoulès site. A basal medium (SM1) prepared at $\mathrm{pH} 3.5$ and 4.5 was supplemented with $327 \mathrm{mg} . \mathrm{L}^{-1} \mathrm{Zn}$ and $75 \mathrm{mg} . \mathrm{L}^{-1} \mathrm{As}(\mathrm{V})$ (using respectively 16 g.L $\mathrm{L}^{-1} \mathrm{ZnSO}_{4}$ and 10 g.L $\mathrm{L}^{-1} \mathrm{As}(\mathrm{V})$ anaerobic stock solutions). Active cultures precipitating yellow-white precipitates were sub-cultured in $40 \mathrm{~mL}$ basal medium supplemented with As and major metals 
present in Carnoulès water: $2 \mathrm{~mL}$ of $\mathrm{Fe}(\mathrm{II})$ solution (final concentration $1 \mathrm{~g} . \mathrm{L}^{-1}$ ), $2 \mathrm{~mL}$ of metals solution, $0.5 \mathrm{~mL}$ of As(III) solution (final concentration $100 \mathrm{mg} \cdot \mathrm{L}^{-1}$ ) and $0.2 \mathrm{~mL}$ of $\mathrm{As}(\mathrm{V})$ solution (final concentration $40 \mathrm{mg} \cdot \mathrm{L}^{-1}$ ). Concentrated $\mathrm{Fe}(\mathrm{II})$ and metals solutions were prepared under $\mathrm{N}_{2}$ atmosphere, with oxygen-free ultrapure water acidified at $\mathrm{pH} 4.5$ with $\mathrm{H}_{2} \mathrm{SO}_{4}$. Fe(II) solution contained, per litre, $99.2 \mathrm{~g}$ of $\mathrm{FeSO}_{4} .7 \mathrm{H}_{2} \mathrm{O}$. Metals solution contained, per litre: $\mathrm{Al}_{2}\left(\mathrm{SO}_{4}\right)_{3} .18 \mathrm{H}_{2} \mathrm{O}, 13.6 \mathrm{~g} ; \mathrm{MnSO}_{4} \cdot \mathrm{H}_{2} \mathrm{O}, 368 \mathrm{mg} ; \mathrm{NiSO}_{4} .6 \mathrm{H}_{2} \mathrm{O}, 44 \mathrm{mg} ; \mathrm{ZnSO}_{4} .7 \mathrm{H}_{2} \mathrm{O}$, $1.77 \mathrm{~g}$; $\mathrm{CuSO}_{4} .5 \mathrm{H}_{2} \mathrm{O}, 32 \mathrm{mg}$. Concentrated $\mathrm{As}(\mathrm{III})$ and $\mathrm{As}(\mathrm{V})$ solutions (10 g.L $\mathrm{L}^{-1}$ As) were prepared as described in Battaglia-Brunet et al. (2002). Two sulfate-reducing cultures were obtained after five sub-cultures at $\mathrm{pH} 3.5$ and 4.5; they were mixed to obtain the sulfatereducing microbial consortium used to inoculate the bioreactor. A pellet of this inoculum was stored at $-20^{\circ} \mathrm{C}$ for DNA extraction and bacterial taxonomic identification.

\subsubsection{Operating conditions}

The bioreactor first worked in passive down-flow condition for 199 days, during which the microbial activity was exclusively supported by the nutrients present in the solid filling materials (Battaglia-Brunet et al., 2016). During this phase, the feed solution was a synthetic mine water prepared adding the following components to $1 \mathrm{~L}$ deionized water whose $\mathrm{pH}$ was adjusted with concentrated $\mathrm{H}_{2} \mathrm{SO}_{4}: 2.3 \mathrm{~g} \mathrm{Na}_{2} \mathrm{SO}_{4}, 50 \mathrm{~mL}$ of $\mathrm{Fe}(\mathrm{II})$ solution, $50 \mathrm{~mL}$ of metals solution, $10 \mathrm{~mL}$ of $\mathrm{As}(\mathrm{III})$ solution and $2.5 \mathrm{~mL}$ of $\mathrm{As}(\mathrm{V})$ solution. The $\mathrm{pH}$ dropped from 4.5 to 3.0 in 60 days. The present experiment started at Day 200, after this passive phase, using real spring S1 mine water ( $\mathrm{pH} 3.3$ ) amended with $250 \mathrm{mg} . \mathrm{L}^{-1}$ of glycerol as feed. The bioreactor was down-flow fed during 26 days. Down-flow configuration consumes less energy than upflow however it increases the phenomena of preferential flow paths and clogging. Then, downflow was changed to up-flow feeding (day 226). At last, from day 315, the column was up-flow 
fed with the spring SSR ( $\mathrm{pH} 4.0$ ) mine water complemented with $50 \mathrm{mg} . \mathrm{L}^{-1}$ glycerol. The temperature was maintained constant at $25^{\circ} \mathrm{C}$.

\subsubsection{Monitoring of the bioreactor}

The outlet solution was collected and maintained under $\mathrm{N}_{2}$ atmosphere. Once a day, the outlet bottle was weighted to measure flow-rate. $\mathrm{pH}$ was measured and $5 \mathrm{~mL}$ of bioreactor outlet were filtrated at $0.45 \mu \mathrm{m}$, acidified with nitric acid and stored at $5^{\circ} \mathrm{C}$ until $\mathrm{As}, \mathrm{Fe}$ and $\mathrm{Zn}$ analyzes. The remaining effluent was stored at $5^{\circ} \mathrm{C}$ under $\mathrm{N}_{2}$ atmosphere until treatment in the aerobic bioreactor. Feed was sampled once a week to check $\mathrm{pH}$ and chemical composition. Total As was analyzed by oven AAS (Varian SpectrAA 220Z), Zn and Fe by flame AAS (VARIAN SpectrAA 300). Total organic carbon was quantified by hot oxidation with sodium persulfate (method NF EN 1484) and acetate was analyzed by ionic chromatography. Punctually (on days 201, 219, 288, 309 and 367), $5 \mathrm{~mL}$ of slurry were collected from top, middle and bottom septa with a sterile syringe, filtrated on a sterile $0.22 \mu \mathrm{m}$ cellulose acetate filter and the filters were stored at $-20^{\circ} \mathrm{C}$ for biomolecular analyzes. At the end of the experiment, the column was opened in a glovebox under $\mathrm{N}_{2}$ atmosphere. Samples of the filling material were stored at $-20{ }^{\circ} \mathrm{C}$ for biomolecular analyzes, and other samples were stored under $\mathrm{N}_{2}$ for mineralogical analyzes. After the bioreactor dismantling, "biocompound" particles were recovered, rinsed with deionized water and dried at $40^{\circ} \mathrm{C}$ for $24 \mathrm{~h}$ then weighted to estimate the amount of consumed material.

\subsubsection{Composition of the inoculated sulfate-reducing consortium and evolution of the} bacterial community structure in the column 
Microbial DNA was extracted from the $-20^{\circ} \mathrm{C}$ stored samples, i.e. pellet of the inoculum, frozen filters and filling materials (sampled at the end of the experiment), with the FastDNA Spin Kit for soil applying a mechanical lysis at speed 5 during $30 \mathrm{~s}$. Bacteria composing the inoculum were identified by cloning and sequencing of the $16 \mathrm{~S}$ rRNA gene. Briefly, about $1400 \mathrm{bp}$ of the gene were amplified from the extracted microbial DNA with primers $8 \mathrm{~F}$ (5'AGAGTTTGATCMTGGCTCAG-3') and 1406R (5'-GACGGGCGGTGTGTRCA-3'), and the purified PCR product was cloned into a PCR®4-TOPO vector, according to the manufacturer instructions (Invitrogen). 32 plasmids carrying correct-length insert were sequenced by the GATC company with primers T7 end T3 targeting the vector. Consensus sequences were manually verified and aligned with ClustalW, and distances on unambiguous nucleotide sequences were determined by DNADist, using applications implemented in the BioEdit software (Hall, 1999). Operating taxon units (OTU) were built with retrieved sequences sharing more than 98\% identities. Distances between most related Genbank 16S rRNA gene sequences of known bacteria, obtained by Blastn (http://www.ncbi.nlm.nih.gov/blast/Blast.cgi), and defined OTU sequences were determined by DNADist on 1372 aligned and unambiguous nucleotides. In addition, about $1.9 \mathrm{~kb}$ of the $d s r \mathrm{AB}$ gene encoding the dissimilatory bisulfite reductase involved in reduction of sulfate, were amplified with primers DSR1F (5'-ACSCAYTGGAARCACG-3') and DSR42R (5'GTGTARCAGTTDCCRCA-3'), cloned and sequenced as described. Consensus $d s r$ AB gene sequences sharing more than $98 \%$ identities by DNADist were grouped in OTU and compared to Genbank reference sequences by Blastn. Most related reference and OTU $d s r \mathrm{AB}$ gene sequences were translated into amino acids sequences, aligned and distances were calculated by ProtDist (implemented in BioEdit software) on 552 unambiguous amino acids. Sequences reported in this study are available under GenBank accession numbers MZ476566-MZ476597 (16S rRNA gene sequences) and MZ497397 to MZ497410 (dsrAB gene sequences). 
The evolution of the structure of the bacterial community in the bioreactor was monitored by 16S rRNA gene CE-SSCP genetic fingerprints. About 200 bp of the V3 region of the bacterial 16S rRNA gene were amplified from DNAs (column samples and clones representing each OTU from the inoculum) with the reverse primer w34 (5'-TTACCGCGGCTGCTGGCAC-3'), 5' end-labelled with the fluorescent dye FAM, and the forward primer w49 (5'ACGGTCCAGACTCCTACGGG-3'). Diluted PCR products (100 to 200 fold, to avoid saturation of the fluorescent signal) were heat-denaturated $\left(95^{\circ} \mathrm{C}, 10 \mathrm{~min}\right)$ in HiDi Formamide (Applied BioSystems) and submitted to a non-denaturating electrophoresis using the polymer CAP and an ABI 310 genetic analyzer (Life Technologies), as already described (BattagliaBrunet et al., 2012). Internal DNA standard (Genescan 600-LYZ, Life Technologies) was used to calibrate the runs. DNA fragments of $200 \mathrm{bp}$ from columns' samples and inoculum clones were run concomitantly in the same CE-SSCP capillary electrophoresis. Matching migration pattern was used to assign a clone to a signal of the community patterns and determine if OTU maintained or not in the column. Fingerprint profiles were aligned and compared with BioNumerics version 7.6 software (Applied Maths).

\subsubsection{Characterization of the precipitates}

Black pouzzolana and yellow precipitate samples were analyzed using XRD. XRD measurements were performed using a specifically designed anoxic cell with CoKa radiation using a Panalytical X'Pert Pro diffractometer. Samples were grinded and suspended in ethanol within an anaerobic chamber before being deposited on a Si single-crystal low-background sample holder. Data were collected between 5 and $80^{\circ} 2 \theta$ with a $0.033^{\circ} 2$ step, counting 2 hour per sample. The yellow precipitate around pozzolana grains was observed using electron microscopy associated with microanalysis (SEM-EDXS analysis) on a GEMINI ZEISS Ultra55 
Field Emission Gun Scanning Electron Microscope operating at $15 \mathrm{kV}$. Observations and microanalysis were performed using backscattering electron signal and a Bruker QUANTAX Energy dispersive X-ray spectrometer, respectively. For synchrotron based X-ray absorption spectroscopy, the set of As-sulfide references considered in this study is detailed in Le Pape et al. (2017). Briefly, experimental XAS spectra obtained on the column samples were compared to the ones of amorphous orpiment $\left(\mathrm{am}_{-} \mathrm{As} \mathrm{s}_{2} \mathrm{~S}_{3}\right)$, crystalline orpiment $\left(\mathrm{As}_{2} \mathrm{~S}_{3}\right)$, and realgar $(\mathrm{AsS})$, minerals that are representative of an S-bound local molecular environment. As(V)- and As(III)-sorbed ferrihydrites were used as reference compounds for O-bound local molecular environment. As K-edge XANES and EXAFS spectra were collected at $15 \mathrm{~K}$ (He crysostat) in both transmission and fluorescence mode on the SAMBA beamline (SOLEIL, France) using a $\mathrm{Si}(220)$ double-crystal monochromator. Samples were always kept under inert atmosphere to avoid oxidation. The incident energy was calibrated by measuring the LIII-edge of an Au foil recorded in double transmission. Scans were averaged, normalized and background substracted using the Athena software. Linear combination fitting of XANES spectra were performed over the -20 to $60 \mathrm{eV}$ energy range.

\subsection{Aerobic step}

Effluents from the anaerobic bioreactor were treated in an aerobic bioreactor whose design was described in Fernandez-Rojo et al. (2017b). Briefly, it was composed of 4 rectangular polyvinyl chloride channels $(1 \mathrm{~m}$ length $\times 0.06 \mathrm{~m}$ width $\times 0.06 \mathrm{~m}$ depth $)$ equipped with a double envelope for temperature regulation $\left(20 \pm 0.8^{\circ} \mathrm{C}\right)$. One channel was used for the present experiment. A canvas was placed on the bottom of the channel to provide a rough surface for the adhesion of the biogenic precipitate. A peristaltic pump (Gilson, Minipuls 3) supplied the channel inlet with 
$245 \mathrm{AMD}$ at a flow rate that determined the water residence time, here $\sim 300 \mathrm{~min}$. A second peristaltic pump was necessary to pump the fluid out of the channel and to maintain the water level at specific height $(4 \mathrm{~mm})$. A valve was positioned at the end of outlet tube for sample collection. Prior to the treatment, a "conditioning" step was required to allow the development of an active Fe-oxidizing biofilm. During this step, the aerobic bioreactor was fed with 0.5 $\mathrm{mL} \cdot \mathrm{min}^{-1}$ of water S1, corresponding to a residence time (RT) of $324 \pm 30 \mathrm{~min}$. Inlet and outlet water was collected at regular time intervals for dissolved $\mathrm{Fe}(\mathrm{II})$ and total dissolved $\mathrm{Fe}$ determination until steady-state was reached with respect to Fe(II) oxidation. After steady-state achievement (19 days), the channel was successively fed with (1) the anaerobically-treated spring S1 water and (2) the anaerobically-treated spring SSR water. Efficiency of the aerobic step was assessed by monitoring the inlet and outlet water chemistry. Analyzes included measurement of $\mathrm{pH}$, the determination of total concentrations of dissolved $\mathrm{Fe}(\mathrm{II})$ using spectrophotometry, and total dissolved Fe, Zn and As using ICP-MS, after $0.2 \mu \mathrm{m}$ filtration. Arsenic redox speciation was determined using HPLC-ICP-MS. Details of these analytical procedures are reported in Fernandez-Rojo et al. (2017).

\section{Results}

\subsection{Anaerobic bioreactor}

\subsubsection{Evolution of physic-chemical parameters}

During the down-flow feeding phase with spring S1, As removal efficiency averaged $64 \pm 4 \%$ (157 mg.L $\mathrm{L}^{-1}$ As in the feed, 46 to $71 \mathrm{mg} . \mathrm{L}^{-1}$ in the outlet) for a measured residence time of 298 $\pm 26 \mathrm{~h}$ (Fig. 2A and 2B) whereas within the same time, $\mathrm{Zn}$ removal (Fig. 2C) varied from 2 to 
$25 \%$ (24 mg. $\mathrm{L}^{-1} \mathrm{Zn}$ in the feed, 16 to $23 \mathrm{mg} . \mathrm{L}^{-1}$ in the outlet) and Fe removal (Fig. 2D) from 10 to $30 \%$ (1270 mg. $\mathrm{L}^{-1} \mathrm{Fe}$ in the feed, 84 to $1146 \mathrm{mg} \cdot \mathrm{L}^{-1}$ in the outlet).

Substantial increase of Zn (Fig. 2C) concentration in the effluent after 208 days occurred concomitantly to effluent $\mathrm{pH}$ decrease (Fig. 2E), consequence of clogging of the filling material that resulted in disconnections of feeding pipe. The change (day 226) from down-flow to upflow configuration improved the efficiency of the bioreactor for As removal, that was higher than $85 \%$ from day 245 to day 290 (Fig. 2B). As removal declined slightly with the decrease of residence time from $300 \mathrm{~h}$ to $250 \mathrm{~h}$ after day 245 (event 1 on Fig. 2) but recovered at day 260. The decrease of the mine water $\mathrm{pH}$ from 3.1 to 2.9 after day 270 (event 2 on Fig. 2) also induced transient rise of As concentration in the outlet. A delay of 4-5 days was still observed between the source of disturbance and the rise of As concentration in the outlet because of the high residence time. After day 290, a new decrease in residence time from $250 \mathrm{~h}$ to $70 \mathrm{~h}$ (event 3 on Fig. 2) induced a worsening of As removal that stabilized around $65 \%$. Zn concentration followed the same evolution as As but with variations of higher amplitude. The events that affected As removal by $15 \%$ affected $\mathrm{Zn}$ removal by $90 \%$. After day 290 , the decrease of residence time resulted in a very low level of $\mathrm{Zn}$ removal (less than 10\%). During all the upflow feeding period, Fe was not removed (Fig. 2D). The $\mathrm{pH}$ always increased: while fed with real mine water at $\mathrm{pH}$ close to 3 , the $\mathrm{pH}$ in the outlet ranged from 4.3 to 4.8 (Fig. 2E).

Changing fed water from S1 to SSR corresponded to a decrease in Fe, $\mathrm{Zn}$ and As concentrations and higher $\mathrm{pH}$ of the feed (event 4 on Fig. 2). After a transient period during which parameters were influenced by the change of feed water quality, from day 312 to day 330, complete removal of $\mathrm{As}$ and $\mathrm{Zn}$ was obtained. When the residence time in the bioreactor was 
progressively decreased from 70 to $30 \mathrm{~h}$ (Fig. 1A), As and Zn were always almost entirely removed from SSR water (Fig. 2B and 2C) and Fe was not precipitated (Fig. 2D).

Most of both As and Zn was precipitated in the bottom half of the column (Fig. SM2), so the separation of $\mathrm{As}$ and $\mathrm{Zn}$ inside the column using different filling compositions was not achieved. Acetate was always found in the outlet during the monitoring, however acetate concentration in the outlet was $50 \%$ to $99 \%$ lower than the theoretical concentration that would result from the incomplete oxidation of glycerol (Table SM3), except at the end of experiment with spring SSR water, when the bioreactor was in a phase of degraded efficiency. At the end of experiment, the visual appearance of the biocompounds and their weight did not differ significantly from those of fresh biocompounds, suggesting they have not been biodegraded in the bioreactor.

\subsubsection{Composition of the inoculum and evolution of the bacterial community in the column}

The 32 sequences of the 16S rRNA gene retrieved from the sulfate-reducing consortium enriched from the Carnoulès site were classified into three OTU. The dominant OTU (90.6\% of the sequences) shared $99.1 \%$ identity on the 16S rRNA gene sequence with the acidophilic sulfate-reducing bacterium Desulfosporosinus sp. PFB (Sen and Johnson, 1999). Another Desulfosporosinus-related OTU represented $6.3 \%$ of the sequences and showed more than $3 \%$ differences on the 16S rRNA gene with the dominant OTU; it shared $97.7 \%$ and $97.8 \% 16 \mathrm{~S}$ rRNA gene identities with Desulfosporosinus sp. OK and Desulfosporosinus sp. OL isolated from an AMD (sequences available in Genbank under numbers MT359229 and MT359230). The closest described Desulfosporosinus species most related (96-97\% identity) to these two OTU were D. lacus, D. meridiei, D. orientis, D. fructosivorans and D. auripigmenti. The third OTU grouping $3.1 \%$ of the sequences was related (99.7\% $16 \mathrm{~S}$ rRNA gene identity) to the 
Propionibacteraceae strain H7p isolated from Carnoulès acid mine drainage (Delavat et al., 2012); except for its tolerance to low pH, no data is currently available on its metabolism.

Sixteen dissimilatory bisulfite reductase (DsrAB) sequences retrieved from the inoculum formed two related OTU sharing $97.4 \%$ identity on their DsrAB aminoacids sequences. The closely related (85.6\% identity) DsrAB sequence to both OTU belonged to the acidophilic Desulfosporosinus sp. DB isolated from an AMD (Karnachuk et al., 2009), and the closest described species were Desulfosporosinus adidiphilus, D. acididurans and D. meridiei with to the Desulfosporosinus genus are present in the sulfate-reducing inoculum enriched from Carnoulès site.

The evolution of fingerprints of the bacterial community sampled during time and location in the column are presented in Fig. 3. Fingerprints were quite similar at the top, middle and bottom of the column, showing a homogeneous distribution of the bacteria in the bioreactor. At days 288 and 309, the structure of the community has evolved and only two of the peaks detected at day 219 remained largely dominant. Changes in operating conditions, i.e. upflow fed and $\mathrm{pH}$ decrease from 3.1 to 2.9, may have favored the corresponding bacteria. The change from spring S1 to SSR site water from day 309 to the end of the monitoring (day 367) did not affect much of feeding with synthetic mine water (Battaglia-Brunet et al., 2016), was one of the dominant throughout the monitoring. Its presence regardless of the condition applied to the column emphasizes its ability to maintain itself under the different conditions applied to the column, in particular a $\mathrm{pH}$ of 3 of the feed water. It was also found on the filling material sampled at the 
end of the monitoring (data not shown), confirming its presence in the biofilm attached on the solid support. No signal corresponding to the Propionibacteraceae bacterium found in the inoculum was evidenced, indicating that its proportion amongst other bacteria represented, if present, only as a small fraction of the total community.

\subsubsection{Characterization of the precipitates}

In the samples from the column, i.e. black pouzzolana and yellow precipitate, analyzed using XRD (Fig. SM4-A), no As-bearing phase was observed. The composition is in line with usual mineral compounds used in pouzzolana, e.g. feldspars. In the yellow precipitate recovered around the pouzzolana grains, only gypsum was observed as crystalline material. However, very low amplitude reflexions as well as large bumps above the background suggest the presence of amorphous or nanocrystalline materials.

Both XANES and EXAFS spectra obtained at the As K-edge for the different samples collected in the column were compared to reference materials representative for specific As local molecular environments. Realgar (AsS) and amorphous orpiment $\left(\mathrm{am}_{-} \mathrm{As}_{2} \mathrm{~S}_{3}\right)$ were used as references for sulfur bound As, and As(III)-sorbed ferrihydrite and As(V)-sorbed ferrihydrite were used as proxies of oxygen bound As. Linear combination fitting analysis performed on As K-edge XANES spectra shows that the samples mainly contained amorphous orpiment (89 to $100 \%$ ) and a minor amount of oxygen bound As(III) (0 to $13 \%$ ) (Fig. SM4-B and Table SM4C). Even considering the low quality of EXAFS signal for some of the samples (Fig. SM4-D), both EXAFS oscillations and Fast Fourier Transform confirm the major occurrence of amorphous orpiment in the samples recovered from the column experiment (Fig. 4). As both XANES and EXAFS spectra of thiol-bound As(III) are difficult to differ from the one of amorphous orpiment, the presence of such As species cannot be excluded in the samples. In 
addition, the presence of minor amount of oxygen bound As(V) and realgar $(<5 \%)$ cannot be discarded considering the standard uncertainty of XAS-LCF analysis.

In Fig. 4, the image of yellow precipitate was taken in backscattering electron mode, thus the brightest spots indicate the presence of the heaviest elements. In this particular case, the brightness of particles is related to the As content. Both encrusted and non-encrusted bacteria are observed, as well as submicrometric aggregates of spherical particles connected or not with bacteria. All the particles probed using EDXS (1 to 6, Fig. 4) showed a major signal of As and $\mathrm{S}$, which is consistent with arsenic sulfides as the main products of the sulfate-reducing activity of the biofilm. Only traces of Fe and Zn were detected in the EDXS spectra, confirming that As was the main element to precipitate as biogenic sulfide in the bioreactor. In addition to the large occurrence of aggregates of spherical nanoparticles in the biofilm, nanospheres can be observed on the surface of bacterial cells (Fig. 4A). This observation would be consistent with those of Newmann (1997) who observed the extracellular precipitation of orpiment nanoparticles on sulfate-reducing bacteria mineralizing arsenic.

\subsection{Coupling with aerobic step}

The aerobic step was tested as a preliminary evaluation of the feasibility of biological oxidation of $\mathrm{Fe}(\mathrm{II})$ and increase of As removal in the sulfate-reduction bioreactor effluent, that contained also organic substances, potentially inhibitors of $\mathrm{Fe}(\mathrm{II})$ and $\mathrm{As}(\mathrm{III})$ bio-oxidation. This treatment induced a decrease of $\mathrm{pH}$ and Fe concentration: 7\% (S1) and 9\% (SSR) removal were obtained within 300 minutes (Fig. 5). Concerning As, for spring S1, nearly 90\% removal was obtained in the anaerobic bioreactor, and the aerobic step improved the overall removal, decreasing both $\mathrm{As}(\mathrm{III})$ and $\mathrm{As}(\mathrm{V})$ concentrations by $33 \%$ and $44 \%$, respectively. These results 
represent a gain of $6 \%$ removal for $\mathrm{As}(\mathrm{III})$ and $4 \%$ for $\mathrm{As}(\mathrm{V})$ considering the initial composition of the mine water. Conversely, with spring SSR, the aerobic step did not induce any As removal. Surprisingly, a release of As(III) was observed in these conditions. The aerobic step had no effect on $\mathrm{Zn}$ concentration.

\section{Discussion}

Up to now, laboratory continuous experiments dedicated to the biological precipitation of arsenic sulfide were fed with synthetic solutions (Battaglia-Brunet et al., 2012; Altun et al., 2014; Rodriguez-Freire et al., 2014, 2015). Here, a real As-rich acidic mine water, of complex composition, was used to confirm the feasibility of continuous anaerobic precipitation of orpiment at low $\mathrm{pH}$, in accordance with batch experiment data (Le Pape et al., 2017). The present experiment with real mine water and glycerol supply started on day 200, after the bioreactor was fed with synthetic mine water during 199 days under entirely passive conditions (Battaglia-Brunet et al., 2016). During this previous experimental phase, a progressive decrease of the bioreactor efficiency had been observed, linked to the exhausting of substrates initially placed into the column. Semi-passive sulfate-reducing bioreactors are increasingly seen as a viable option for highly contaminated AMD (Lounate et al., 2020). One of the objectives of the present study was to evaluate the precipitation of $\mathrm{As}$ and $\mathrm{Zn}$ in the sulfate-reducing bioreactor working in semi-passive condition, while Fe remained in solution, knowing that: (1) As is toxic and cannot be valorized, thus should be precipitated in the smallest volume of waste as possible, (2) $\mathrm{Zn}$ must be removed during the sulfate-reducing step because the oxidation step will not remove it, (3) Fe can be efficiently removed downstream by passive microbial or chemical oxidation step, co-precipitating the residual As. Furthermore, as Fe is the most concentrated 
metal in Carnoulès AMD, avoiding its precipitation in the anaerobic bioreactor will save organic substrates and prevent rapid clogging.

The theoretical mass balance comparing our process configuration with a classical lime treatment directly applied to the spring S1 AMD (Fig. 6) suggests that the amount of Ascontaminated solid waste could be drastically decreased applying a sulfate-reduction step followed by aerobic oxidation. Moreover, the classical lime application could not remove $\mathrm{Zn}$ from water unless reaching pH 9.5 (Murdock et al., 1993), thus implying a supplementary final step of acid addition.

The direct feeding of sulfate-reducing bacteria with the acid mine waters S1 et SSR was possible, in spite of the low $\mathrm{pH}$, because iron, although present in high concentration, is mainly under the Fe(II) form in Carnoulès water (Casiot et al., 2003). The sulfate reduction induced an increase of one unit $\mathrm{pH}$ along the experiment. However, the $\mathrm{pH}$ in the outlet remained acidic, contrary to previous studies (Battaglia-Brunet et al., 2012; Altun et al., 2014; Rodriguez-Freire et al., 2014, 2015), where the electron donor was not limiting, supporting an extended sulfatereduction activity and resulting in a $\mathrm{pH}$ value higher than $\mathrm{pH} 5-6$ in the outlet. Here, the moderate $\mathrm{pH}$ increase, linked to the limited substrate supply, allowed separating Fe, that remained in solution, from $\mathrm{Zn}$ and As that were precipitated together during periods of efficient microbial activity. However, the anaerobic bioreactor was more efficient to remove As than Zn: the weakening of bacterial activity always affected $\mathrm{Zn}$ precipitation more than As removal during the experiment with spring S1. Precipitation of amorphous orpiment is favored at low $\mathrm{pH}$ (Eary, 1992): the more acid the medium is, the more orpiment precipitation is efficient. With spring S1 water, le Pape et al. (2017) already showed that As precipitation was more rapid than that of $\mathrm{Zn}$. With spring SSR, the feed $\mathrm{pH}(\mathrm{pH}$ 4) was already higher than the value necessary for $\mathrm{ZnS}$ precipitation, that could explain the efficient removal of both $\mathrm{Zn}$ and As from this mine water. Mattes et al. (2011) already reported efficient removal of both As and $\mathrm{Zn}$ from 
a smelter landfill seepage ( $\mathrm{pH}$ 5.9), through a real scale anaerobic passive bioreactor filled with a mixture of limestone, quartz sand and organic waste.

443

444

445

Here, considering that production of sulfide was mainly coupled to incomplete degradation of glycerol (reaction 1), and consumption of sulfide occurred according to reactions (2) and (3), the total amount of glycerol necessary to precipitate all As $(2 \mathrm{mM})$ and $\mathrm{Zn}(0.3 \mathrm{mM})$ present in S1 should be $4.4 \mathrm{mM}$, i.e. $405 \mathrm{mg} \mathrm{L}^{-1}$. Yet, the bioreactor feed contained only $250 \mathrm{mg} \mathrm{L}^{-1}$ glycerol, a limiting concentration that should not have been sufficient for the precipitation of both As and $\mathrm{Zn}$, whereas the complete removal of these two elements was observed during some periods of the experiment.

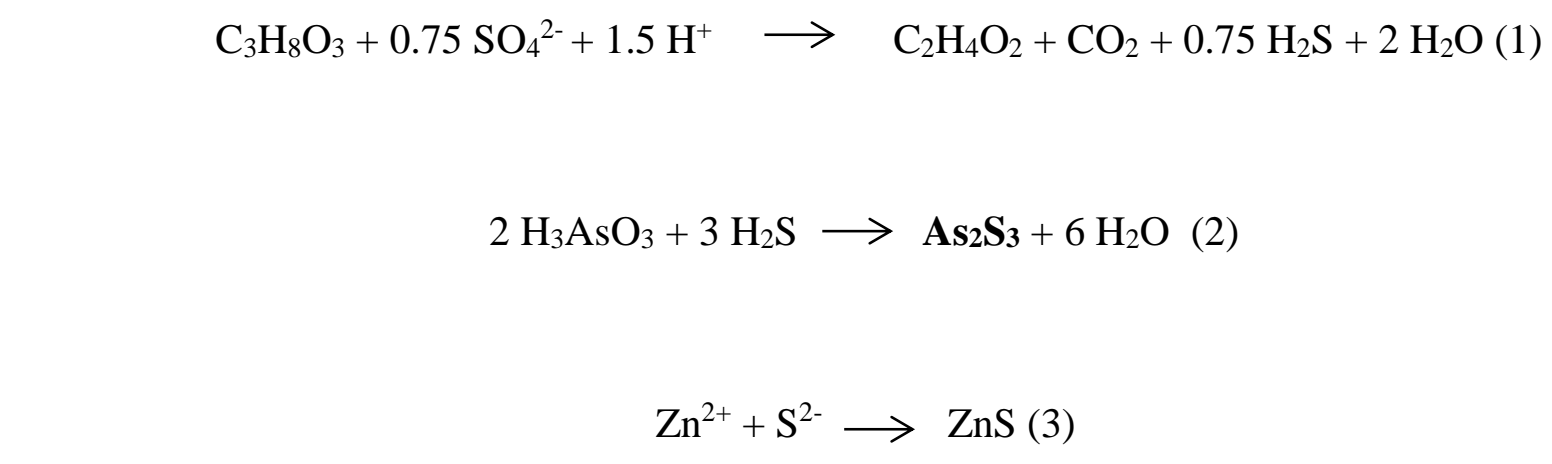

This result may be explained by the complete oxidation of glycerol, according to reaction (4), that would produce 2.3 times more $\mathrm{H}_{2} \mathrm{~S}$ than reaction (1). As a fact, acetate concentration in the bioreactor outlet was lower than the theoretical concentration corresponding to the incomplete oxidation of all the glycerol supplied with the feed water. Nancucheo and Johnson (2014) already observed a decrease of acetate concentration in a sulfate-reducing bioreactor fed with glycerol, when the working $\mathrm{pH}$ was decreased from 4.5 to 3.0. The switch from incomplete to complete oxidation of glycerol was accompanied by a change in the bacterial community structure. The solid filling material, initially loaded with agar, yeast extract and glycerol, could also slowly release organic molecules that played the role of complementary electron donors. 
Initially, the bioreactor was inoculated with a sulfate-reducing consortium mainly composed SRB affiliated to the Desulfosporosinus genus. Two distinct OTU were retrieved; they showed less than $97 \%$ sequence identity on their 16S rRNA genes, and 96-97\% identities with described Desulfosporosinus species (D. lacus D. meridiei, D. orientis, D. fructosivorans and D. auripigmenti). If we consider a cut-off value at the species level of $98.7 \%$ or above on the 16S rRNA gene (Rossi-Tamisier et al., 2015), the two-retrieved OTU may represent new acidophilic species of the Desulfosporosinus genus. The OTU sequences had higher identity values with yet undescribed acidophilic isolates of the genus: $99 \%$ between the dominant OTU and Desulfosporosinus sp. PFB (Sen and Johnson, 1999) and $98 \%$ between the second SRB OTU and Desulfosporosinus sp. OK and OL (MT359229 and MT359230 Genbank accession numbers). The Desulfosporosinus genus comprises several members known to reduce sulfate, in acidic conditions, and often isolated from mining sites (e.g. Sen and Johnson, 1999; Karnachuk et al., 2009; Alazard et al., 2012; Sánchez-Andrea et al., 2015). All these Desulfosporosinus strains are incomplete oxidizers using glycerol to reduce sulfate and produce acetate. Based on community fingerprints, one of the SRB OTU was among the dominant microorganism in the bioreactor, all along the experiment. Desulfosporosimus-like $16 \mathrm{~S}$ sequences were already detected in bioreactors treating As-containing acid solutions (BattagliaBrunet et al., 2012) and Gonzales et al. (2019) observed a SRB affiliated to Desulfosporosinus acididurans becoming dominant in their bioreactor treating a synthetic AMD in continuous mode. Moreover, analysis of microbial communities revealed the widespread presence of Desulfosporosinus-related sulfate reducers in diverse SRB reactors treating AMD from laboratory to real scale (Habe et al., 2020).

In the present study, mineralogical observations of the precipitates formed in the bioreactor were globally in line with those obtained from batch experiments, with AMD from the same 
site, in comparable conditions (Le Pape et al., 2017). However, if the major occurrence of amorphous orpiment is strongly suspected from SEM-EDXS and confirmed by XANES and EXAFS spectroscopy, no realgar was detected in the form of nanowires in the biofilm observed by SEM-EDXS. Thus, the processes occurring within the continuous column experiment would be representative of the early stages of As reduction and precipitation processes identified in the batch experiment system, before reduction of orpiment into realgar (Le Pape et al., 2017).

When the outlet water from the anaerobic reactor was treated in aerobic condition, partial oxidation of iron and a decrease of $\mathrm{pH}$ were observed. The iron removal rate with S1 and SSR waters were $1.1 \times 10^{-7}$ and $0.9 \times 10^{-7} \mathrm{~mol} . \mathrm{L}^{-1} \cdot \mathrm{s}^{-1}$ respectively, that is of the same range but lower than the iron removal rates previously reported during direct aerobic treatment of this AMD in the same reactor $\left(1.3-2.4 \times 10^{-7} \mathrm{~mol} . \mathrm{L}^{-1} \cdot \mathrm{s}^{-1}\right.$, Fernandez-Rojo et al., 2017). The hydraulic residence time was only $300 \mathrm{~min}$, so largely lower than that applied in the anaerobic step. The conditions of this aerobic step remain to be optimized. Gonzales et al. (2019) observed the complete oxidation of the ferrous iron present in the outlet of a SRB bioreactor, corresponding to nearly $1 \mathrm{mM}$, in $1 \mathrm{~h}$ aeration. Here, some As was removed from $\mathrm{S} 1$ water previously treated anaerobically, however with SSR water, some release of As(III) occurred. This phenomenon may be linked to the sharp shift from S1 to SSR water compositions, inducing a decrease of As concentration in the feed (17 to $3 \mathrm{mg} \mathrm{L}^{-1}$ respectively), and might be linked to the sorptiondesorption equilibrium of $\mathrm{As}(\mathrm{III})$ associated with the iron precipitates, or to the solubility of As(III)-shwermannite accumulated in the reactor during the previous step. A decrease of As(III)-oxidation activity might also have occurred. The activity of As(III)-oxidizing bacteria may be influenced by the residual organic molecules from the anaerobic reactor. As(III)oxidizing bacteria can grow heterotrophically or autotrophically (Santini et al., 2000; BattagliaBrunet et al., 2006; Garcia-Dominguez et al., 2008). In particular, strains of Thiomonas, the 
main As(III)-oxidizing genus found in Carnoulès AMD (Hovasse et al., 2016), are facultative chemolithoautotrophs that grow optimally in mixotrophic media containing reduced inorganic sulfur compounds and organic supplements (Bryan et al., 2009; Slyemi et al., 2011). Tardy et al. (2018) observed a stimulation of As(III)-oxidation by yeast extract, in the AMD of Carnoulès mine. However, the effect of organic substrates might depend on the nature of the supplied molecules: how the bacterial communities of the biofilms inside the aerobic channel are impacted by the anaerobic effluent would require further analyzes.

\section{Conclusions}

The feasibility of arsenic precipitation as orpiment in a sulfate-reducing bioreactor fed with two types of real As-rich mine drainage waters was demonstrated at laboratory scale. Limitation of sulfate-reduction by low supply of carbon and energy source allowed the removal of most arsenic while iron remained in the water. Precipitation of zinc in the sulfate-reducing reactor was efficient with the low-concentrated AMD, whereas optimization is still needed in order to stabilize this process with the most concentrated AMD. The separation of arsenic from iron in such type of mine water may be beneficial in terms of most hazardous waste mass, as the main part of the arsenic would be concentrated as $\mathrm{As}_{2} \mathrm{~S}_{3}$. The net consumption of glycerol for a given As and $\mathrm{Zn}$ removal could be lower than initially expected because this substrate can be entirely and not incompletely degraded. Downstream oxidation and precipitation of iron, besides additional As removal, was proven to occur in an aerobic laboratory bioreactor, although not optimized in the present study. Whereas the two treatment steps studied here allowed the removal of 70 to $95 \%$ of As, in two different AMD streams, a down-stream lime drain would be necessary in order to increase the final $\mathrm{pH}$ of the treated water, and remove the residual As and Fe by co-precipitation. Results support the feasibility of applying simple combination of low-cost treatment options, including semi-passive SRB bioreactor, for the remediation of Asrich AMDs. 


\section{Declarations}

542 Funding This research was financially supported by the French ANR (Agence Nationale de la 543 Recherche) in the frame of IngECOST-DMA project (ANR-13-ECOT-0009).

544 Conflict of Interest The authors declare they have no conflict of interest.

545 Availability of data and material All data are available on request to the corresponding author 546 (e.mail: f.battaglia@brgm.fr)

547 Authors contribution F. Battaglia-Brunet: Conceptualization, Writing, Supervision; L. 548 Fernandez-Rojo: Investigation, Editing; M. Hery: Editing; C. Casiot: Conceptualization, 549 Methodology, Supervision, Writing, Editing; P. Le Pape: Investigation, Writing, Editing; H. 550 Tris: Investigation; S. Touzé: Conceptualization; G. Morin: Supervision, Editing; C. Joulian: 551 Investigation, Supervision, Writing, Editing.

Figure captions

554

555

556

557

558

559 560

Figure 1. Bioreactor filling and feeding modes, down-flow (A), up-flow (B), and pictures taken just after filling (C) and at the end of experiment (D).

Figure 2. Evolution of parameters in the bioreactor fed with springs S1 then SSR mine water. A: residence time (h), B: arsenic concentration $\left(\mathrm{mg}_{\mathrm{L}} \mathrm{L}^{-1}\right), \mathrm{C}$ : zinc concentration (mg. $\left.\mathrm{L}^{-1}\right), \mathrm{D}$ : iron concentration (mg.L ${ }^{-1}$ ), E: pH. Numbered vertical lines show specific events: (1) and (3) decrease of residence time; (2) decrease in feed $\mathrm{pH}$, (4) change from spring S1 to spring SSR. 
The $\mathrm{pH}$ value increased from 4.0 in the feed to 4.5-5.0 in the outlet, except during the last days of experiment, probably because of the decrease of residence time from 40 to $30 \mathrm{~h}$ (Fig. 2E).

Figure 3. Evolution of $16 \mathrm{~S}$ rRNA gene CE-SSCP fingerprints at the bottom (B), mid (M) and top (T) of the column. *: signal matching with the signal of the Desulfosporosinus OTU originally dominant in the inoculated bacterial mixed culture. Horizontal scale: migration position of detected signals determined from electrophoretic scans.

Figure 4. Analysis of As mineralogy and speciation in yellow deposits that precipitated at the surface of pouzzolana grains in the column experiment. (A) SEM image in backscattering electron mode showing the biofilm morphology. Plain orange arrows indicate mineralized encrusted bacterial cells; dashed orange arrows indicate non-mineralized cells; Blue arrows indicate aggregates of spherical nanoparticles. (B) Microanalyses performed using Energy dispersive X-Ray spectroscopy (EDXS) at different spots of approximately $1 \mu \mathrm{m}^{3}$ on the biofilm sample (spots 1 to 6 in red on the image). The emission spectra 1 to 6 show the presence of As and $\mathrm{S}$ as main constitutive elements (C) XANES spectra and (D) EXAFS spectra of the bulk sample (black) and of amorphous orpiment reference sample (red). Bulk solid speciation of As in the biofilm is similar to that of amorphous orpiment (E) Fast Fourier transform of the EXAFS signal. Additional data relative to XAS analysis for different samples of the column are available in SM4 (Figures SM4B and SM4D, and Table SM4C). 
Figure 5. Evolution of S1 (A) and SSR (B) water parameters before treatment, after the anaerobic step (SRB) and in the outlet of the aerobic step (OX).

Figure 6. Theoretical mass balance for the treatment of spring S1 AMD by a SRB bioreactor coupled with acidic aerobic step followed by lime addition, compared with simple one-step lime treatment. The percentage of Fe removal as schwertmannite by acidic oxidation is inspired by previous results of Fernandez-Rojo et al. (2017); (a) analytical quantification limit; (b) formula according to Garcia-Rios et al. (2021); (c) solubility of gypsum according to Lebedev and Kosorukov (2017).

\section{References}

Alazard, D., Joseph, M., Battaglia-Brunet, F., Cayol, J.-L., Ollivier, B. (2012). Desulfosporosinus acidiphilus sp. nov.: a moderately acidophilic sulfate-reducing bacterium isolated from acid mining drainage sediments. Extremophiles, 14, 305-312.

Altun, M., Sahinkaya, E., Durukan, I., Bektas, S., Komnitsas, K. (2014). Arsenic removal in a sulfidogenic fixed-bed column bioreactor. Journal of Hazardous Materials. 269, 31-37.

Battaglia-Brunet, F., Dictor, M.-C., Garrido, F., Crouzet, C., Morin, D., Dekeyser, K., Clarens, M. \& Baranger, P. (2002). An arsenic(III)-oxidizing bacterial population: selection, characterization and performance in reactors. Journal of Applied Microbiology, 93(4), 656-667.

Battaglia-Brunet, F., Itard, Y., Garrido, F., Delorme, F., Crouzet, C., Greffie, C., Joulian, C. (2006). A simple biogeochemical process removing arsenic from a mine drainage water. Geomicrobiology Journal, 23(3-4), 201-211. 
Battaglia-Brunet, F., Crouzet, C., Burnol, A., Coulon, S., Morin, D., Joulian, C. (2012).

607

608

609

610

611

612

613

614

615

616

617

618

619

620

621

622

623

624

625

626

627

Precipitation of arsenic sulphide from acidic water in a fixed-film bioreactor. Water Research 46(12), 3923-3933.

Battaglia-Brunet, F., Joulian, C., Casiot, C. (2016). Development of a passive bioremediation process based on sulfate-reduction to treat arsenic-containing acidic mine water. In $\mathrm{P}$. Bhattacharya, M. Vahter, J. Jarsjö, J. Kumpiene, A. Ahmad, C. J. Sparrenbom, G. Jacks, M. E. Donselaar, J. Bundschuh, R. Naidu (Eds), Arsenic Research and Global Sustainability: Proceedings of the Sixth International Congress on Arsenic in the Environment (As2016), CRC Press/Balkema, 2016. 730 p.

Bryan, C. G., Marchal, M., Battaglia-Brunet, F., Kugler, V., Lemaitre-Guillier, C., Lièvremont, D., et al. (2009). Carbon and arsenic metabolism in Thiomonas strains: differences revealed diverse adaptation processes. BMC Microbiology, 9, 127.

Casiot, C., Morin, G., Juillot, F., Bruneel, O., Personné, J.-C., Leblanc, M., Duquesne, K., Bonnefoy, V., Elbaz-Poulichet, F., (2003). Bacterial immobilization and oxidation of arsenic in acid mine drainage (Carnoulès creek, France). Water Research, 37(12), 2929-2936.

Delavat, F., Lett, M.-C., Lièvremont, D. (2012). Novel and unexpected bacterial diversity in an arsenic-rich ecosystem revealed by culture-dependent approaches. Biology Direct, 7, 28.

DeSa, T., Brown, J., Burgos, W. (2010). Laboratory and field-scale evaluation of low-pH Fe(II) oxidation at Hughes Borehole, Portage, Pennsylvania. Mine Water and the Environment, 29, 239-247.

Eary, L. E. (1992). The solubility of amorphous $\mathrm{As}_{2} \mathrm{~S}_{3}$ from 25 to $90^{\circ} \mathrm{C}$. Geochimica et Cosmochimica Acta, 56(6), 2267-2280. 
Fernandez-Rojo, L., Hery, M., Le Pape, P., Braungardt, C., Desoeuvre, A., Torres, E., Tardy, V., Resongles, E., Laroche, E., Delpoux, S., Joulian, C., Battaglia-Brunet, F., Boisson, J., Grapin, G., Morin, G., Casiot, C. (2017). Biological attenuation of arsenic and iron in a continuous flow bioreactor treating acid mine drainage (AMD). Water Research, 123, 594-606.

Fernandez-Rojo, L., Casiot, C., Laroche, E., Tardy, V., Bruneel, O., Delpoux, S., Desoeuvre, A., Grapin, G., Savignac, J., Boisson, J., Morin, G., Battaglia-Brunet, F., Joulian, C., Hery, M. (2019). A field-pilot for passive bioremediation of As-rich acid mine drainage. Journal of Environmental Management, 232, 910-918.

Garcia-Dominguez, E., Mumford A., Rhine, E D., Paschal, A., Young, L. Y. (2008). Novel autotrophic arsenite-oxidizing bacteria isolated from soil and sediments. FEMS Microbioliology Ecology, 66(2), 401-410.

Garcia-Rios, M., De Windt, L., Luquot, L., Casiot, C. (2021). Modeling of microbial kinetics and mass transfer in bioreactors simulating the natural attenuation of arsenic and iron in acid mine drainage. Journal of Hazardous Materials, 405, 124133.

Gibert, O., de Pablo, J., Cortina, J. L., Ayora, C. (2004). Chemical characterisation of natural organic substrates for biological mitigation of acid mine drainage. Water Research 38(19), 4186-4196.

Gonzalez, D. Liu, Y., Villa Gomez, D., Southam, G., Hedrich, S., Galleguillos, P., Colipai, C., Nancucheo, I. (2019). Performance of a sulfidogenic bioreactor inoculated with indigenous acidic communities for treating an extremely acidic mine water. Minerals Engineering, 131, 370-375.

Habe, H., Sato, Y., Aoyagi, T., Inaba, T., Hori, T., Hamai, T., Hayashi, K., Kobayashi, M., Sakata, T., Sato, N. (2020). Design, application, and microbiome of sulfate-reducing 
651

652

653

654

655

656

657

658

659

660

661

662

663

664

665

666

667

668

669

670

671 Kontopoulos, A. (1997). Effluent treatment in the mining industry. S.H. Castro, F. Vegara, and

672

bioreactors for treatment of mining-influenced water. Applied Microbioly and Biotechnoly, 104, $6893-6903$.

Hall, T. A. (1999). BioEdit: a user-friendly biological sequence alignment editor and analysis program for Windows 95/98/NT. Nucleic Acids Symposium Series, 41, 95-98.

Hovasse, A., Bruneel, O., Casiot, C., Desoeuvre, A., Farasin, J., Hery,, M., Van Dorsselaer, A., Carapito, C., Arsène-Ploetze, F. (2016). Spatio-temporal detection of the Thiomonas Population and the Thiomonas arsenite oxidase involved in natural arsenite attenuation processes in the Carnoulès acid mine drainage. Frontiers in Cell and Developmental Biology, 4, 3. www.frontiersin.org/article/10.3389/fcell.2016.00003

Johnson, D. B., Jameson, E., Rowe, O. F., Wakerman, K., Hallberg, K. B. (2009). Sulfidogenesis at low $\mathrm{pH}$ by acidophilic bacteria and its potential for the selective recovery of transition metals from mine waters. Advanced Materials Research, 71-73, 693-696.

Kaksonen, A. H., Puhakka, J. A. (2007). Sulfate reduction based bioprocesses for the treatment of acid mine drainage and the recovery of metals. Engineering in Life Sciences, 7(6), 541-564.

Karnachuk, O. V., Gerasimchuk, A. L., Banks, D., Frengstad, B., Stykon, G. A., Tikhonova, Z. L., Kaksonen, A., Puhakka, J., Yanenko, A. S., Pimenov, N. V. (2009). Bacteria of the sulfur cycle in the sediments of gold mine tailings, Kuznetsk Basin, Russia. Microbiology, 78, 483491.

Kimura, S., Hallberg, K. B., Johnson, D. B. (2006). Sulfidogenesis in low pH (3.8-4.2) media by a mixed population of acidophilic bacteria. Biodegradation, 17, 159-167.

M. A. Sanchez (Eds), University of Conception-Chile. 
673

674

675

676

677

678

679

680

681

682

683

684

685

686

687

688

689

690

691

692

693

694

Lebedev, A. L., Kosorukov, V. L. (2017). Gypsum Solubility in Water at $25^{\circ}$ C. Geochemistry International, 55(2), 205-210.

Lee, G., Bigham, J. M., Faure, G. (2002). Removal of trace metals by coprecipitation with Fe, $\mathrm{Al}$ and Mn from natural waters contaminated with acid mine drainage in the Ducktown Mining District, Tennessee. Applied Geochemistry, 17(5), 569-581.

Murdock, D. J., Fox, J. R. W., Bensley, J. G. (1993). Treatment of acid mine drainage by the high density sludge process. Proceedings America Society of Mining and Reclamation, pp. 241249.

Le Pape, P., Battaglia-Brunet, F., Parmentier, M., Joulian, C., Gassaud, C., Fernandez-Rojo, L., Guigner, J.-M., Ikogou, M., Stetten, L., Olivi, L. Casiot, C., Morin, G. (2017). Complete removal of arsenic and zinc from a heavily contaminated Acid Mine Drainage via an indigenous SRB consortium. Journal of Hazardous Materials, 321, 764-772.

Lounate, K., Coudert, L., Genty, Mercier, G., Blaise, J.-F. (2020) Performance of a Semipassive Sulfate-reducing Bioreactor for Acid Mine Drainage Treatment and Prediction of Environmental Behavior of Post-treatment Residues. Mine Water and the Environment, 39, $769-784$.

Mattes, A., Evans, L. J., Gould, W. D., Duncan, W. F. A., Glasauer, S. (2011). The long term operation of a biologically based treatment system that removes As, S and $\mathrm{Zn}$ from industrial (smelter operation) landfill seepage. Applied Geochemistry, 26(11), 1886-1896.

Nairn, R. W., LaBar, J.A., Strevett, K. A., Strosnider, W. H., Morris, D., Neely, C. A., Garrido, A., Santamaria, D., Oxenford, L., Kauk, K., Carter, S., Furneaux, B. (2010). A large, multi-cell, ecologically engineered passive treatment system for ferruginous lead-zinc mine waters. In 
695 Wolkersdorfer \& Freund (Eds), Mine Water and Innovative Thinking, Proceedings of the IMWA 2010, pp. 255-258.

697

698

699

700

701

702

703

704

705

706

707

708

709

710

711

712

713

714

715

716

Nancucheo, I., Johnson, D. B. (2012). Selective removal of transition metals from acidic mine waters by novel consortia of acidophilic sulfidogenic bacteria. Microbial Biotechnology, 5, 3444.

Nancucheo, I., Johnson, D. B. (2014). Removal of sulfate from extremely acidic mine waters using low pH sulfidogenic bioreactors. Hydrometallurgy, 150, 222-226.

Parvis, A. P., Younger, P. L. (1999). Design, construction and performance of a full-scale compost wetland for mine-spoil drainage treatment at quaking houses. Water and Environment Journal, 13(5), 313-318.

Rodriguez-Freire, L., Sierra-Alvarez, R., Root, R., Chorover, J., Field, J. A. (2014). Biomineralization of arsenate to arsenic sulfides is greatly enhanced at midly acidic conditions. Water Research, 66, 242-253.

Rodriguez-Freire, L., Moore, S. E., Sierra-Alvarez, R., Root, R., Chorover, J., Field, J. A. (2015). Arsenic remediation by formation of arsenic sulfide minerals in a continuous anaerobic bioreactor. Biotechnology \& Bioengineering, 113(3), 522-530.

Rossi-Tamisier, M., Benamar, S., Raoult, D., Fournier, P. E. (2015). Cautionary tale of using 16S rRNA gene sequence similarity values in identification of human-associated bacterial species. International Journal of Systematic and Evolutionary Microbiology, 65, 1929-34.

Santini, J. M., Sly, L. I., Schnagl, R. D., Macy, J. M. (2000). A new chemolithoautotrophic arsenite-oxidizing bacterium isolated from a gold mine: Phylogenetic, physiological, and preliminary biochemical studies. Applied and Environmental Microbiology, 66(1), 92-97. 
Sánchez-Andrea, I., Stams, A.J.M., Hedrich, S., Nancucheo I., Johnson D. B. (2015). Desulfosporosinus acididurans sp. nov.: an acidophilic sulfate-reducing bacterium isolated from acidic sediments. Extremophiles, 19, 39-47.

Sen, A. M., Johnson, D. B. (1999). Acidophilic sulphate-reducing bacteria: candidates for bioremediation of acid mine drainage. Process Metallurgy, 9, 709-718.

Serrano, J., Leiva, E. (2017). Removal of Arsenic using acid/metal-tolerant sulfate reducing bacteria: a new approach for bioremediation of high-arsenic acid mine waters. Water, 9(12), 724 994.

Simate, G. S., Ndlovu, S. (2014). Acid mine drainage: Challenges and opportunities. Journal of Environmental Chemical Engineering, 2(3), 1785-1803.

Slyemi, D., Moinier, D., Brochier-Armanet, C., Bonnefoy, V., Johnson, D. B. (2011). Characteristics of a phylogenetically ambiguous, arsenic-oxidizing Thiomonas sp., Thiomonas arsenitoxydans strain 3AsT sp. nov. Archives of Microbiology, 193, 439-449.

Smiedja, J.A., Wilkin, R. (2003). Preservation of Sulfidic Waters Containing Dissolved As(III). Journal of Environmental Monitoring, 6, 913-916.

Touzé, S., Battaglia-Brunet, F., Ignatiadis, I. (2008). Technical and Economical Assesment and extrapolation of a $200-\mathrm{dm}^{3}$ pilot bioreactor for reduction of sulphate and metals in acid mine waters. Water Air \& Soil Pollution, 187, 15-29.

Walters, E., Hille, A., He, M., Ochmann, C., Horn, H. (2009). Simultaneous nitrification/denitrification in a biofilm airlift suspension (BAS) reactor with biodegradable carrier material. Water Research, 43(18), 4461-4468. 
738 Wang, J. W., Bejan, D., Bunce, N. J. (2003). Removal of arsenic from synthetic acid mine

739 drainage by electrochemical $\mathrm{pH}$ adjustment and coprecipitation with iron hydroxide,

740 Environmental Science and Technology, 37(19), 4500-4506.

741

742 
Table 1. Characteristics of the two water samples treated in this study

\begin{tabular}{|l|l|l|l|l|l|}
\hline Water sample & As mg.L & Zn mg.L & Fe mg.L & SO mg.L $^{-1}$ & $\mathrm{pH}$ \\
\hline Spring S1 & 174 & 26.0 & 1345 & 3700 & 3.29 \\
\hline Spring SSR & 18 & 4.4 & 307 & 1500 & 4.02 \\
\hline
\end{tabular}

744

745 


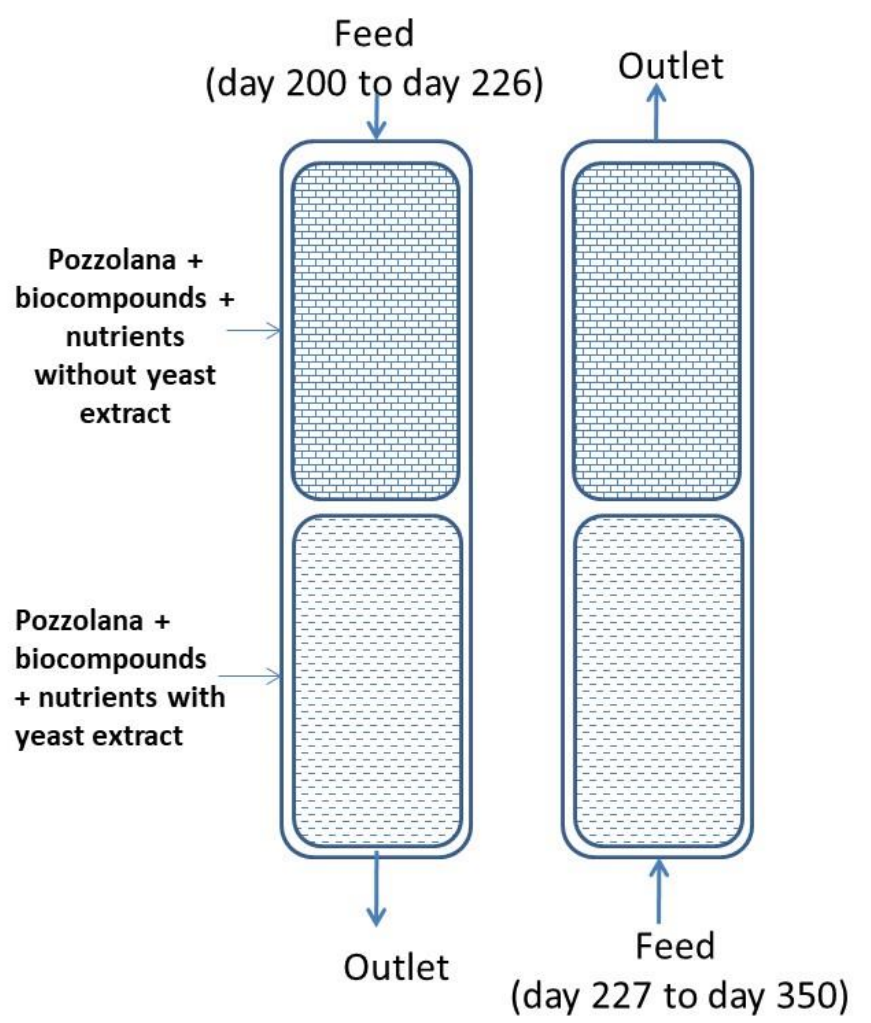

(A)

(B)

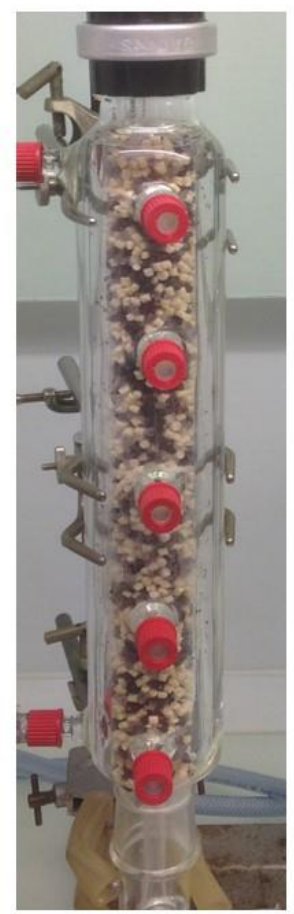

(C)

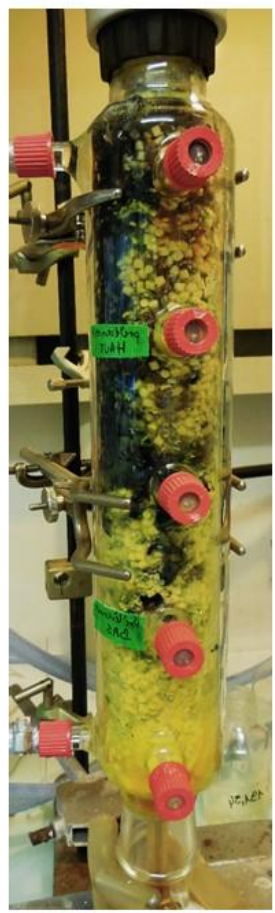

(D) 

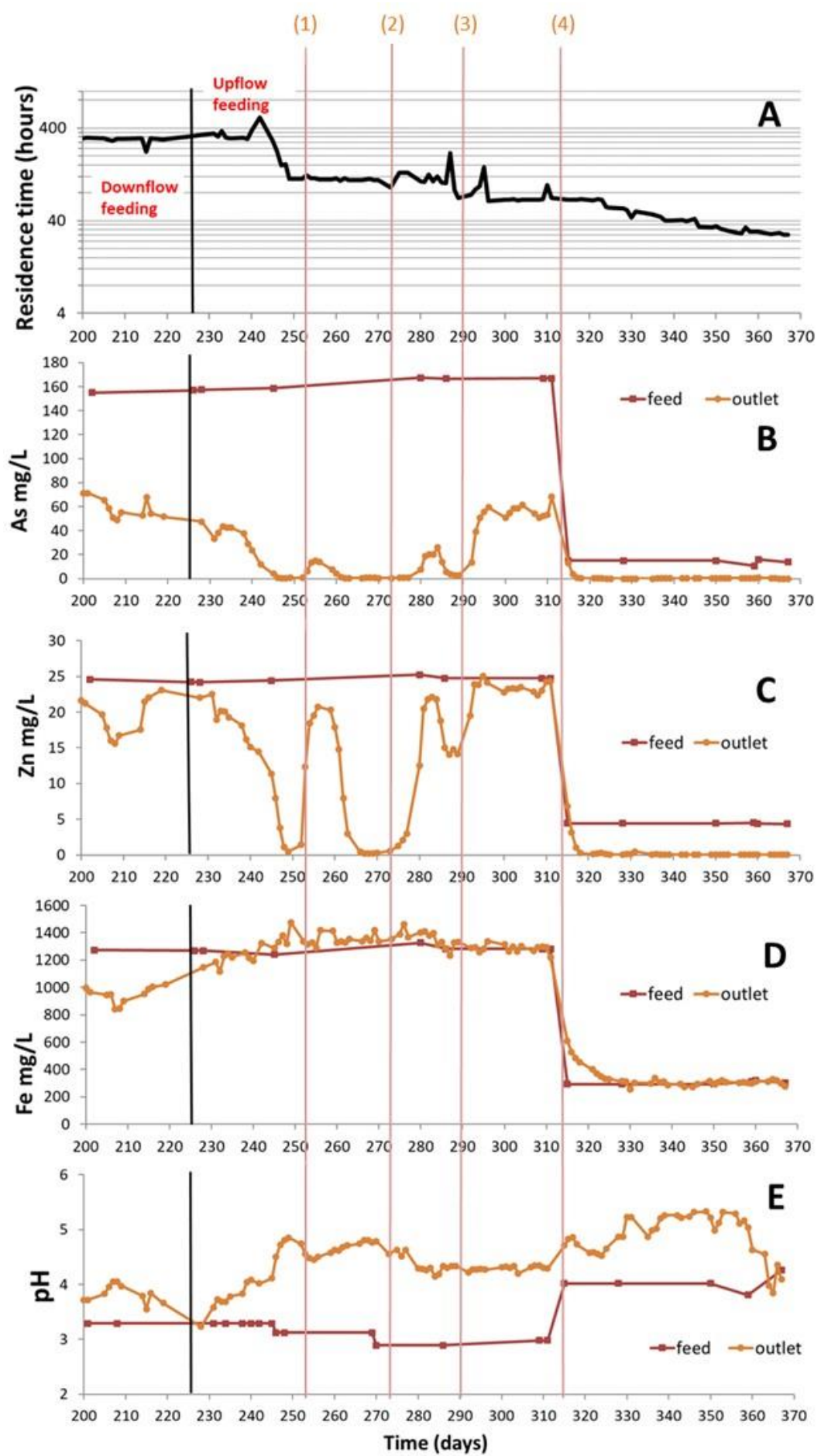

\section{Figure 2}




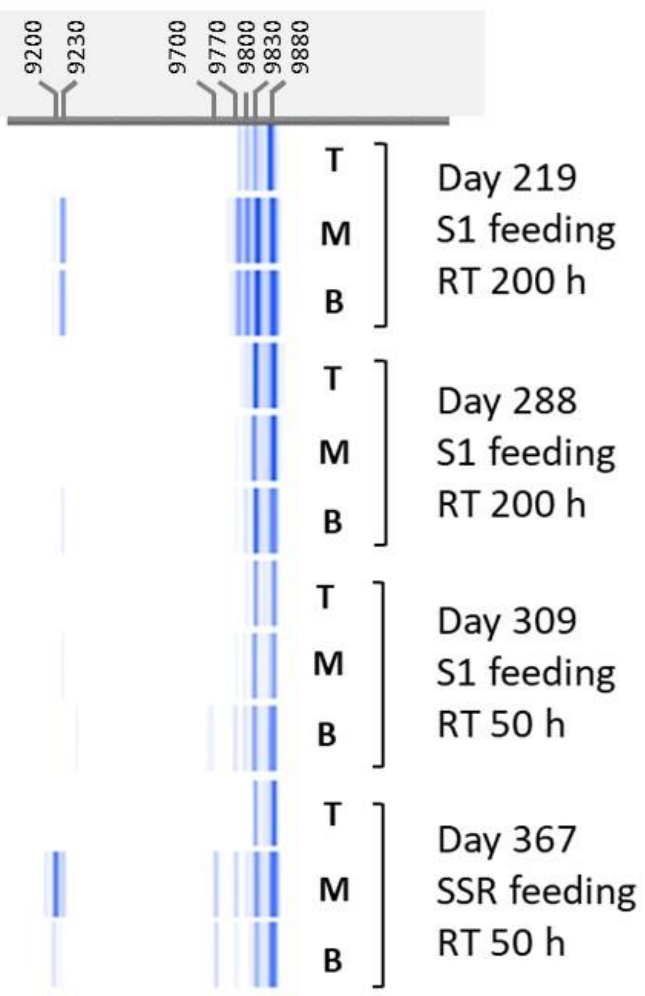

753

Figure 3

754

755 

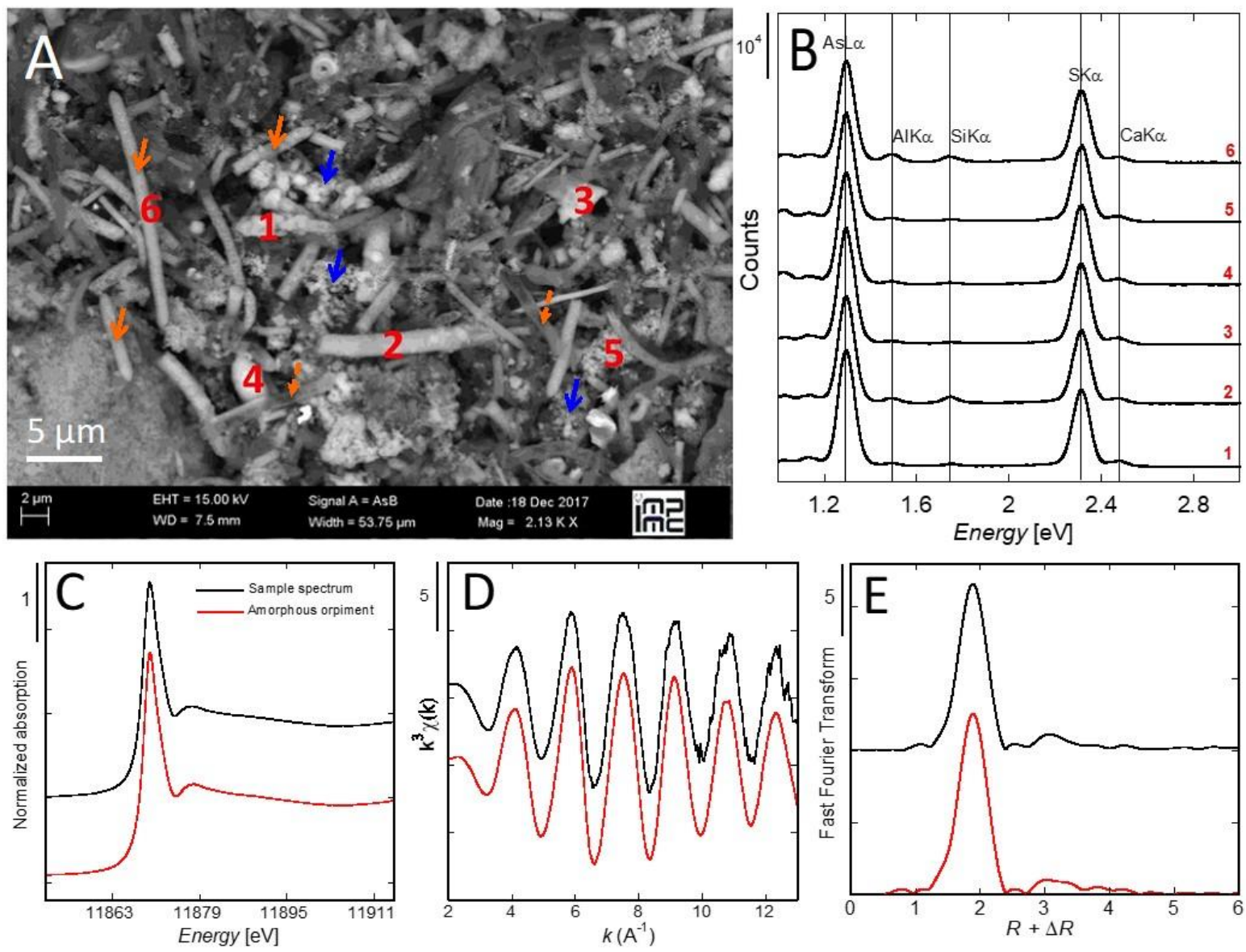

756

Figure 4

757

758 


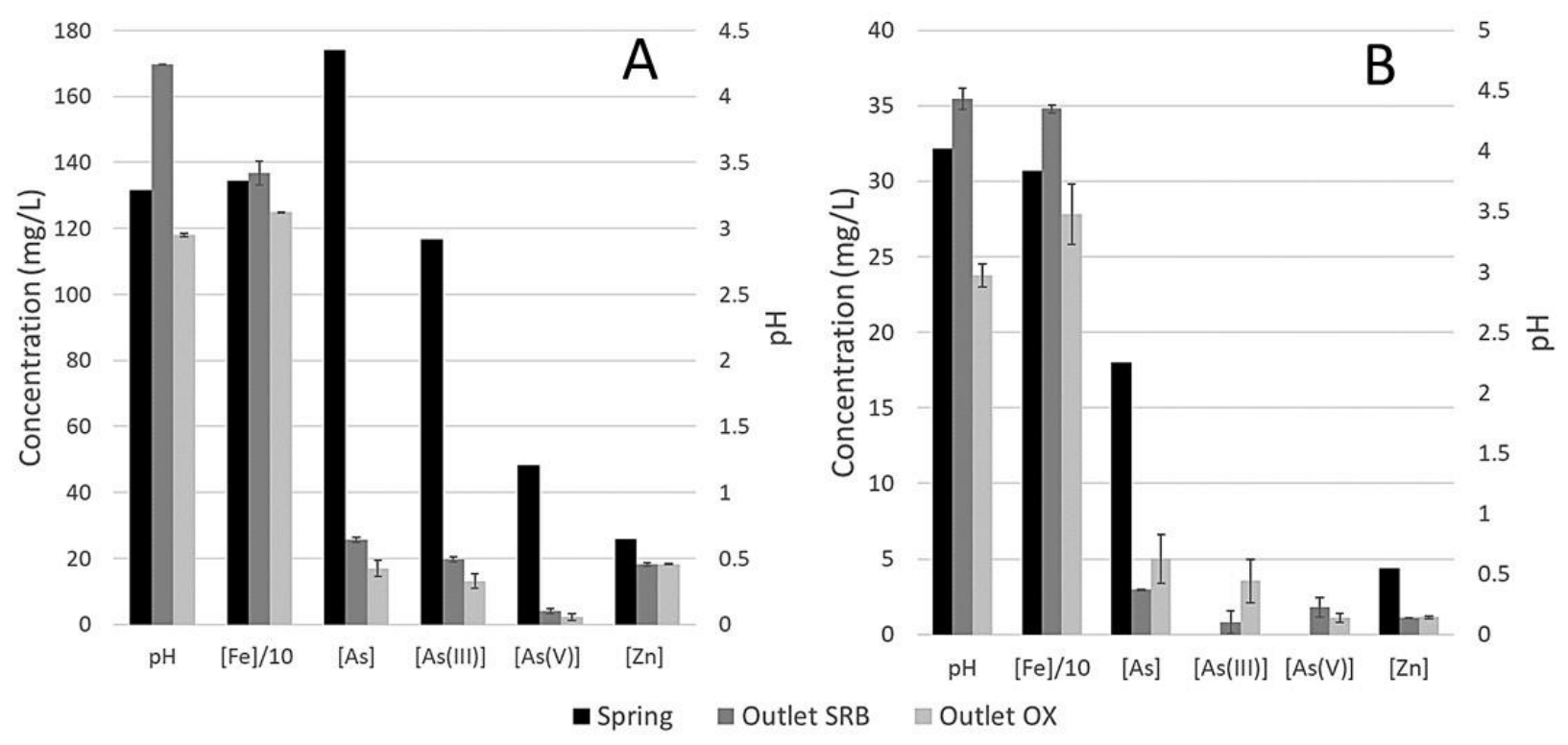

Figure 5

760

761 


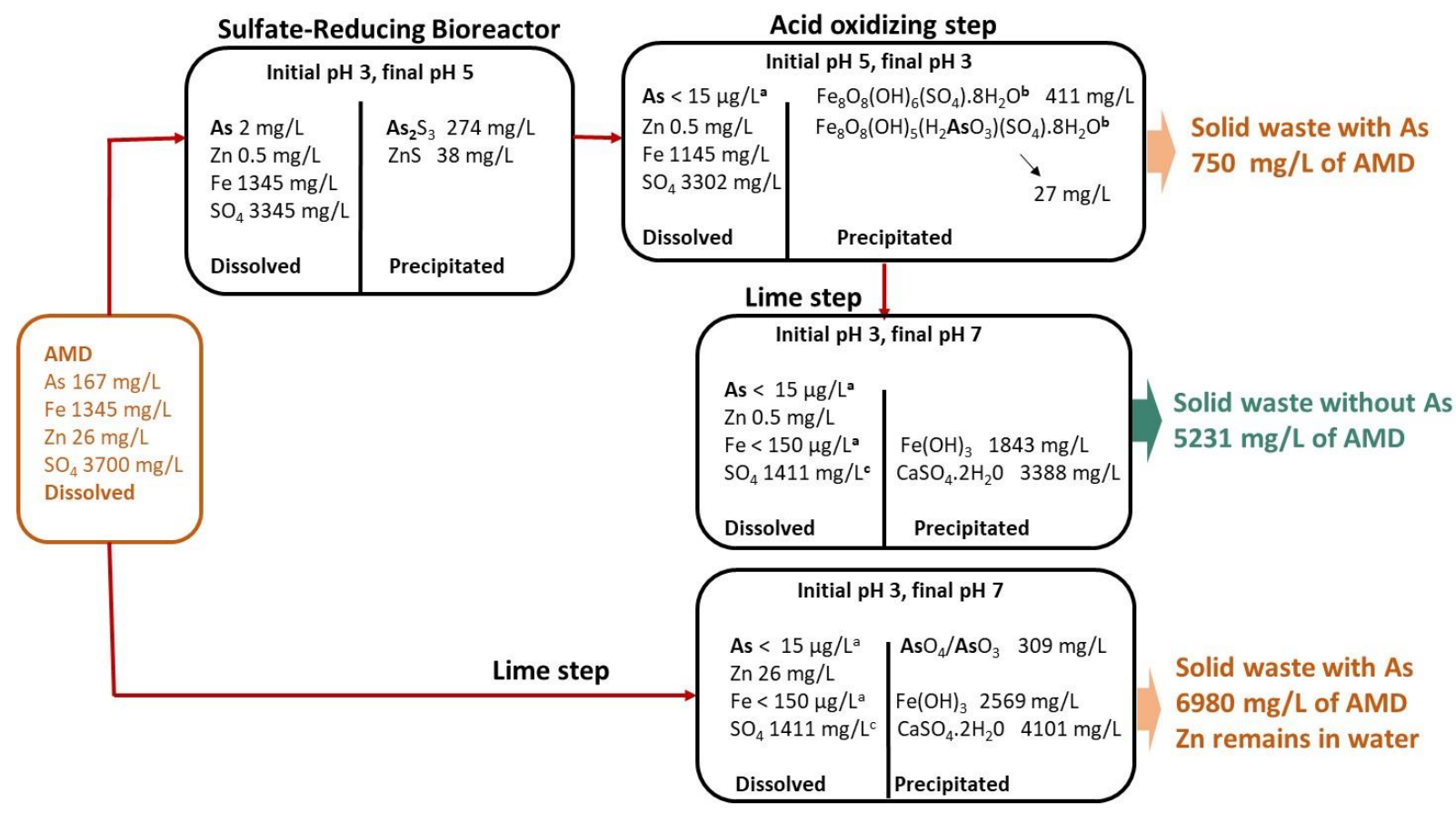




\section{Laboratory-scale bio-treatment of real arsenic-rich acid} mine drainage

Battaglia-Brunet Fabienne, Casiot Corinne, Fernandez-Rojo Lidia, Hery Marina, Le Pape

Pierre, Tris Hafida, Morin Guillaume, Touzé Solène, Joulian Catherine

769

770

771

\section{9}

\section{0}

\section{Supplementary Material SM1. Composition of the basal medium used to enrich sulfate-reducing bacteria}

The basal enrichment medium contained the following ingredients, per litre: $\mathrm{K}_{2} \mathrm{HPO}_{4}, 0.5 \mathrm{~g}$; $\mathrm{NH}_{4} \mathrm{Cl}, 2 \mathrm{~g} ; \mathrm{Na}_{2} \mathrm{SO}_{4}, 1.4 \mathrm{~g} ; \mathrm{MgSO}_{4}, 7 \mathrm{H}_{2} \mathrm{O}, 2 \mathrm{~g}$; glycerol, $0.5 \mathrm{~g}$; yeast extract, $1 \mathrm{~g}$; trace elements solution, $1 \mathrm{ml}$. The $\mathrm{pH}$ of this basal solution was adjusted to 4 .

The trace metals solution composition was the following, per litre: EDTA, $3 \mathrm{~g} ; \mathrm{FeSO}_{4}, 7 \mathrm{H}_{2} \mathrm{O}$, $1.1 \mathrm{~g} ; \mathrm{MnSO}_{4}, 65 \mathrm{mg} ; \mathrm{ZnSO}_{4}, 89 \mathrm{mg} ; \mathrm{NiCl}_{2}, 24 \mathrm{mg} ; \mathrm{Na}_{2} \mathrm{MoO}_{4}, 2 \mathrm{H}_{2} \mathrm{O}, 18 \mathrm{mg} ; \mathrm{H}_{3} \mathrm{BO}_{3}, 0.3 \mathrm{~g}$; $\mathrm{CuCl}_{2}, 2 \mathrm{mg}$ and $\mathrm{CoSO}_{4}, 7 \mathrm{H}_{2} \mathrm{O}, 130 \mathrm{mg}$.

The basal medium was heated to ebullition, then distributed in $50 \mathrm{~mL}$ penicillin flasks equipped with rubber stoppers, flushed with $\mathrm{N}_{2}$, and sterilized by autoclaving $30 \mathrm{~min}$ at $120^{\circ} \mathrm{C}$.

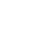

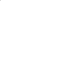

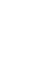

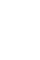

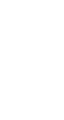

5

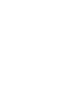

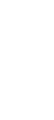

8

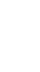


793
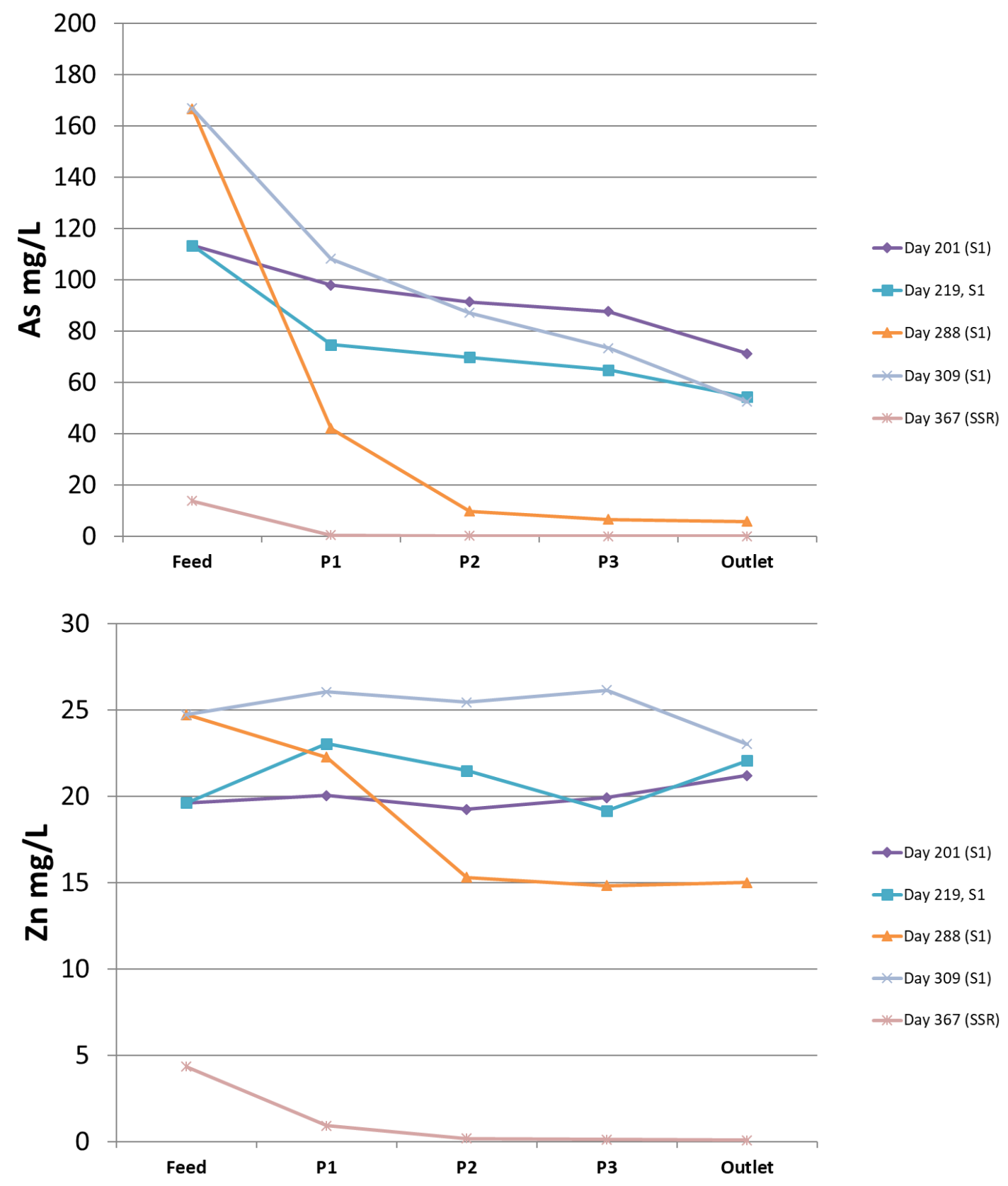

795

796

797

798 
800

801

802

803

804

805

806

807

808

809

810

811

812

813

814

815

Supplementary Material SM3. Acetate and total organic carbon in the anaerobic bioreactor outlet.

Table SM3. Acetate and total organic carbon in the anaerobic bioreactor outlet.

\begin{tabular}{|c|c|c|c|c|}
\hline Day - condition & $\begin{array}{l}\text { Acetate } \\
\mathrm{mg} \cdot \mathrm{L}^{-1}\end{array}$ & $\begin{array}{c}\text { Theoretical } \\
\text { acetate* } \\
\text { mg. } \mathrm{L}^{-1}\end{array}$ & $\begin{array}{c}\text { Organic } \\
\text { Carbon } \\
\text { acetate } \\
\mathrm{mg} \cdot \mathrm{L}^{-1}\end{array}$ & $\begin{array}{l}\text { Total organic } \\
\text { carbon } \mathrm{mg}^{-\mathrm{L}^{-1}}\end{array}$ \\
\hline 201 - S1 downflow & 2.4 & 166 & 0.9 & 62.3 \\
\hline 219 - S1 downflow & 0.5 & 166 & 0.2 & 75.5 \\
\hline $249-$ S1 upflow & 15.5 & 163 & 6.1 & 74.2 \\
\hline $270-$ S1 upflow & 25.5 & 163 & 10 & 27.2 \\
\hline $286-$ S1 upflow & 30.4 & 163 & 12 & 29.9 \\
\hline $308-$ S1 upflow & 44.5 & 163 & 17.5 & 66.3 \\
\hline 359 - SSR upflow & 14.1 & 33 & 6.9 & 35.7 \\
\hline 366 - SSR upflow & 30.1 & 33 & 11.8 & 36.7 \\
\hline
\end{tabular}

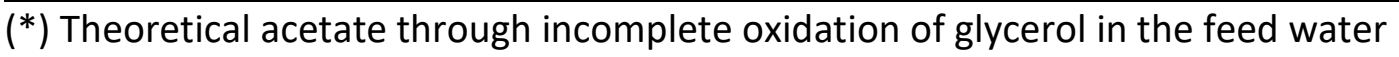
according to $\mathrm{C}_{3} \mathrm{H}_{8} \mathrm{O}_{3}+0.75 \mathrm{SO}_{4}{ }^{2-}+1.5 \mathrm{H}^{+}=>\mathrm{C}_{2} \mathrm{H}_{4} \mathrm{O}_{2}+\mathrm{CO}_{2}+0.75 \mathrm{H}_{2} \mathrm{~S}+2 \mathrm{H}_{2} \mathrm{O}$ 

sampled in the anaerobic reactor

818 Sample 1: Black pouzzolana + yellow deposit

819 Sample 2: Gelatinous yellow colored material

820 Sample 3: Wolly black material

821

822

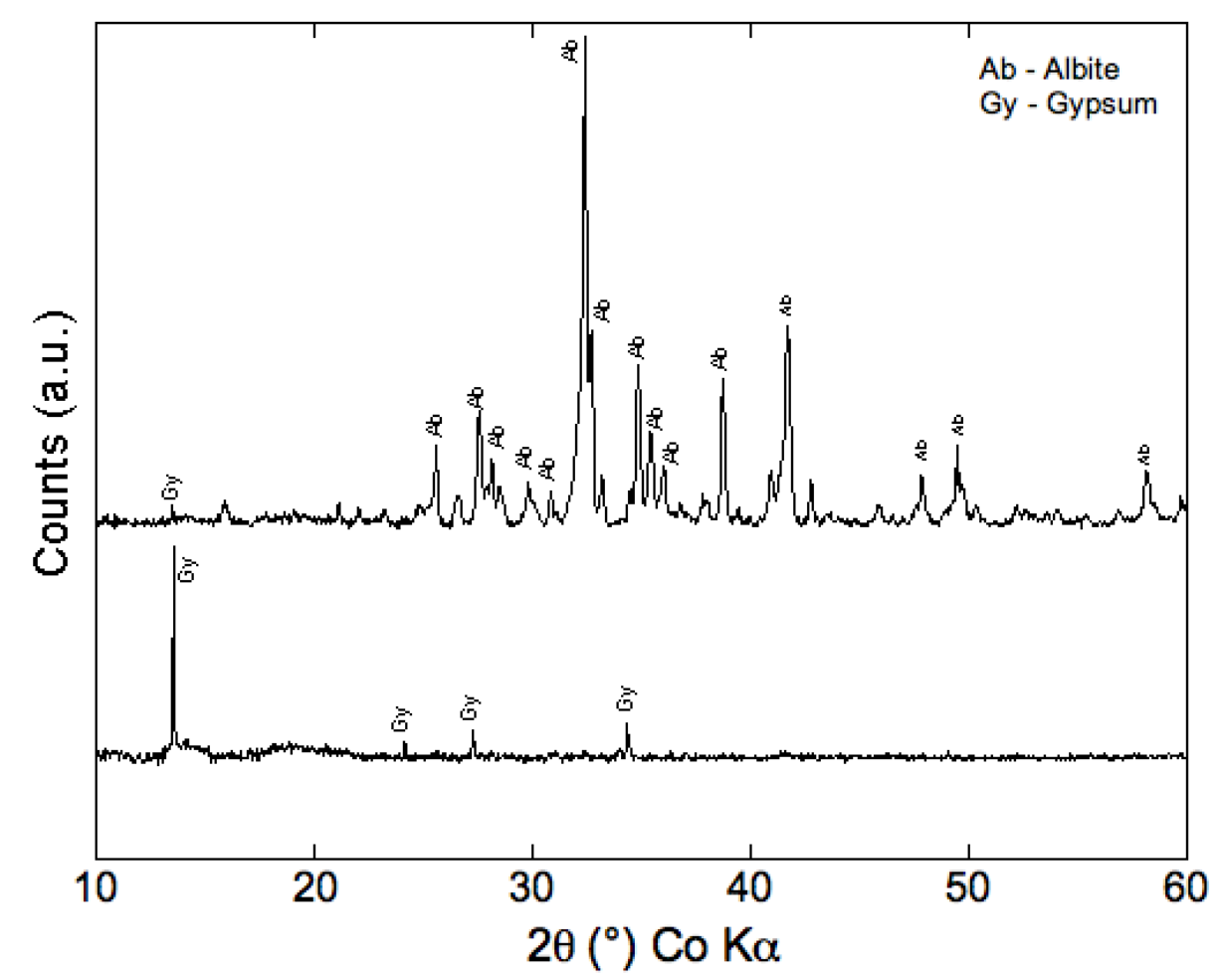


828

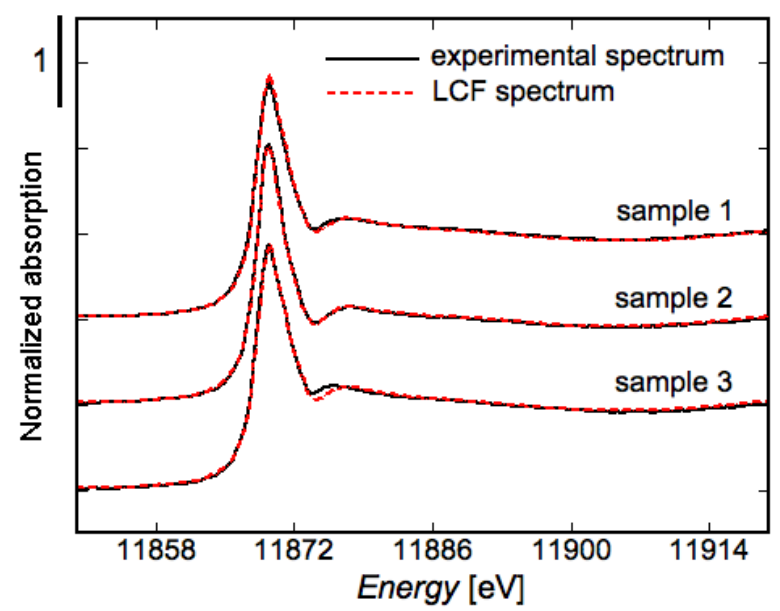

Figure SM4-B - X-ray Absorption Near Edge Structure (XANES) experimental spectra and linear combination fits for samples 1, 2, and 3.

Table SM4-C - Relative contributions of As species in the experimental XANES spectra (Fig. 4) by performing a linear combination fitting procedure with two reference compounds, namely amorphous orpiment (As(III)-S) and arsenite-sorbed ferrihydrite (As(III)-O). R-factor and Redchi ${ }^{2}$ are given as indicators of the quality of fits.
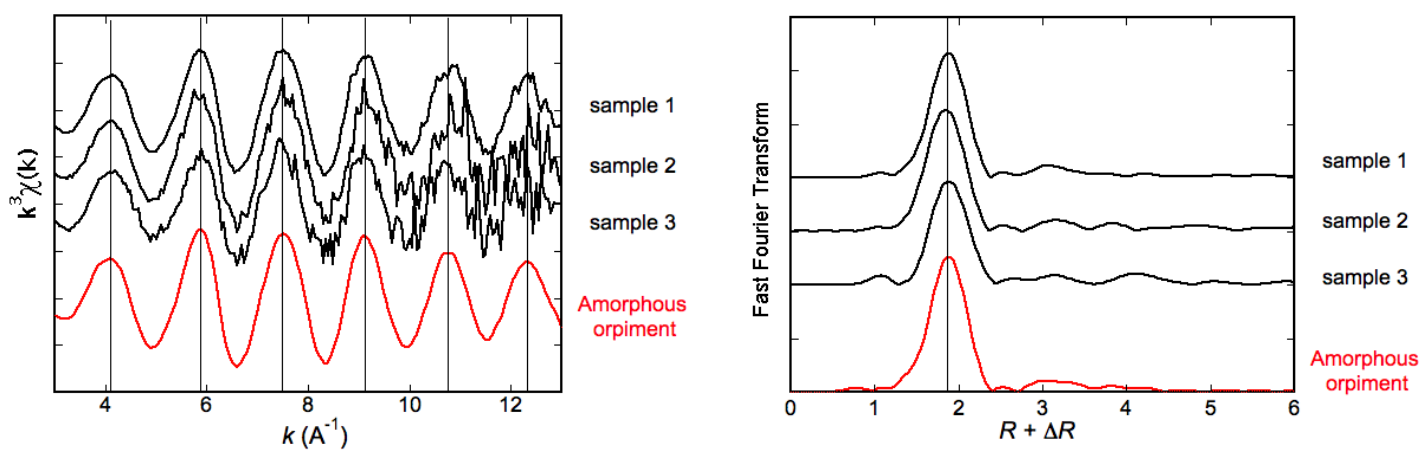

Figure SM4-D - Extended X-Ray Absorption Fine Structure (EXAFS) presented for the experimental spectra of samples 1, 2, and 3 and for the amorphous orpiment reference mineral. 